
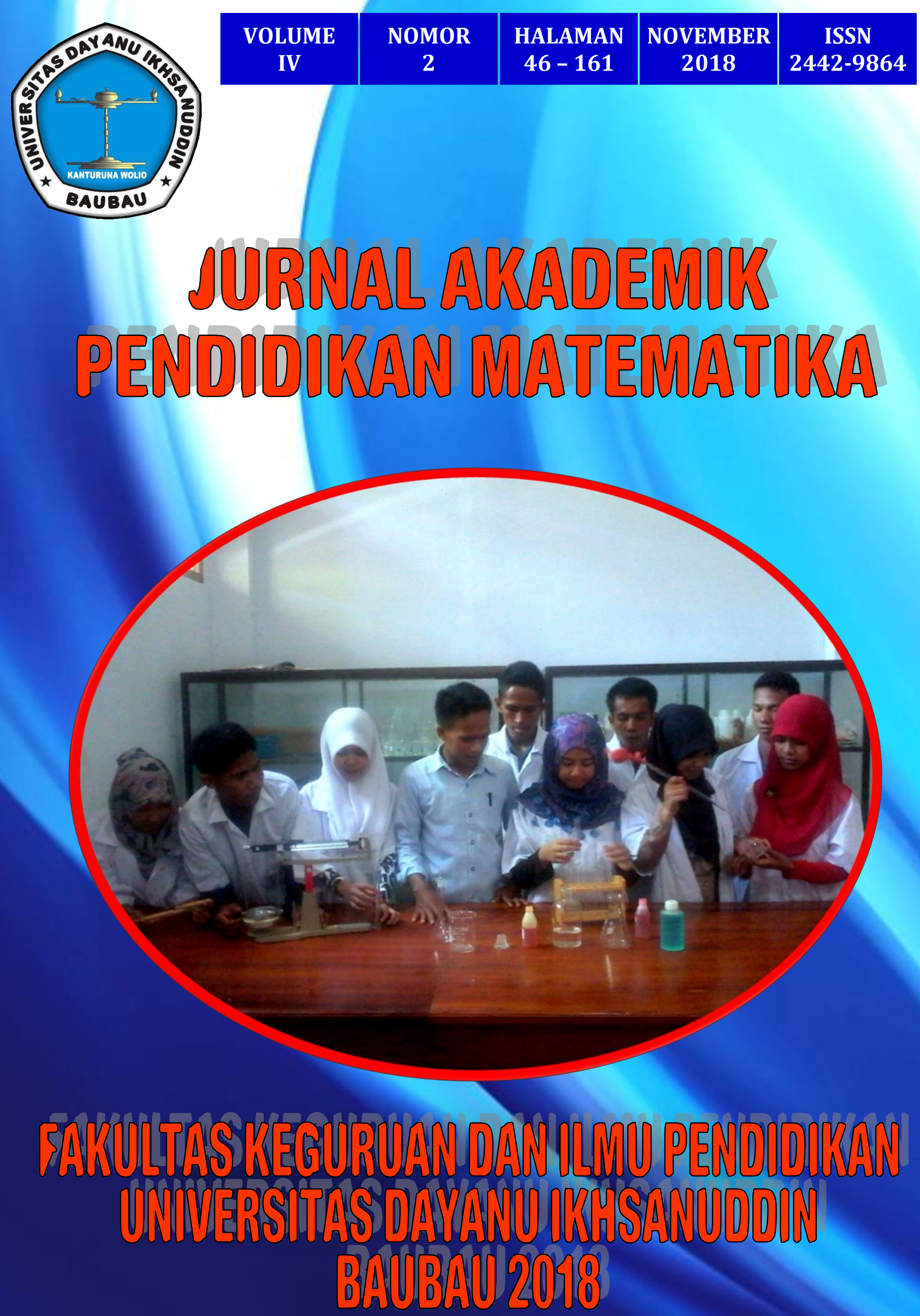


\title{
PENGELOLA REDAKSI
}

\section{Pembina/Penasehat}

Drs. Anwar, M.Pd.

\section{Pengarah}

Dr. Rasmuin, M.Pd.

\section{Pimpinan Redaksi}

Ernawati Jais, S.Si., M.Pd.

\section{Sekretaris}

Afudin La Arua, S.Pd., M.Pd.

\section{Penyunting}

Dian Lestari, S.Pd., M.Pd.

La Eru Ugi, S.Pd., M.Pd.

\section{Sirkulasi}

Hasan Djidu, S.Pd., M.Pd.

Herlawan, S.Pd., M.Pd.

\section{Diterbitkan oleh}

Lembaga Jurnal Akademik Pendidikan Matematika

FKIP Unidayan Baubau

\author{
Alamat Redaksi \\ J1. Dayanu Ikhsanuddin No. 124 Baubau \\ Telp./Fax. \\ E-mail.Jurnal.penmatefkipund@gmail.com
}




\section{KATA PENGANTAR}

Puji syukur kita panjatkan ke hadirat Tuhan Yang Maha Pemurah dan Pengasih karena atas rahmat-Nya Jurnal Akademik Pendidikan Matematika Fakultas Keguruan dan Ilmu Pendidikan Universitas Dayanu Ikhsanuddin Baubau dapat menerbitkan Jurnal Akademik Pendidikan Matematika Volume IV, Nomor 2, November 2018.

Jurnal Akademik Pendidikan Matematika memuat dan menyebar luaskan hasil-hasil penelitian pendidikan dosen, penelitian mahasiswa, penelitian guru, dan penelitian pemerhati pendidikan dari berbagai perguruan tinggi ataupun instansi di Indonesia. Hasil-hasil penelitian yang disampaikan pada jurnal ini hanya terbatas pada bidang matematika dan pendidikan matematika.

Jurnal ini adalah terbitan kelima pada Jurnal Akademik Pendidikan Matematika Fakultas Keguruan dan Ilmu Pendidikan Universitas Dayanu Ikhsanuddin Baubau, olehnya itu Pengelola Redaksi mengharapkan masukan dan kritik membangun dari civitas akademika agar terbitan berikutnya akan makin baik dan berkualitas. Adanya kekurangan-kekurangan pada jurnal ini kiranya dapat dimaklumi.

Atas perhatian pembaca dan semua pihak yang telah memberikan bantuan hingga diterbitkannya jurnal ini diucapkan terima kasih.

Baubau, November 2018

Kaprodi Pend. Matematika,

$\operatorname{ttd}$

Ernawati Jais, S.Si., M.Pd.

NIDN. 0923118003 


\section{DAFTAR ISI}

Pengelola Redaksi

ii

Kata Pengantar

Daftar Isi

iii

iv

Analisis Kemampuan Pemahaman Pengetahuan Mahasiswa pada Mata Kuliah Statistik Matematika

Oleh: Azis, Maya Nurlita

Penggunaan Lampu LED untuk Meningkatkan Pemahaman Konsep PLSV pada Siswa Kelas VII-B di SMP Negeri 18 Baubau

Oleh: Amhari

Peningkatan Penguasaan Operasi Bilangan Bulat dengan Teknik Permainan KocokKocok untuk Siswa Kelas VII A SMP Negeri 3 Baubau

Oleh: Fariati

64-68

Efektivitas Model Pembelajaran Tematik Terhadap Prestasi Siswa Kelas III SD Negeri 1 Kambowa

Oleh: Artati Iriana

$69-73$

Meningkatkan Keterampilan Berhitung Peserta Didik pada Operasi Hitung Bilangan Bulat dengan Penggunaan Media Kelereng Warna Untuk Kelas II Sekolah Dasar

Oleh: Ernawati Jais, Fadly Satryo Guntara All Farisman

IDEA (Identification Ethnomathematic of Architecture) Benteng Keraton Buton: Identifikasi Etnomatematika (Bilangan dan Geometri) pada Arsitektur Benteng Keraton Buton

Oleh: Dian Lestari, Rustam

Efektivitas Model Pembelajaran CTL (Contextual Teaching and Learning) Terhadap Penalaran Matematika Siswa Kelas VIII SMP Negeri 3 Pasarwajo

Oleh: Rahmatia, Norma Usu

Analisis Kesalahan Siswa dalam Menyelesaikan Soal-Soal Operasi Hitung Bilangan Bulat dan Alternatif Pemecahannya Ditinjau Dari Gaya Kognitif Siswa Kelas IV SD Negeri 1 Katobengke Kota Baubau

Oleh: La Eru Ugi, Herlawan.

Pengaruh Strategi Berhitung (Different Strategies) Terhadap Hasil Belajar Matematika Siswa SD Negeri 4 Wameo

Oleh: Anwar, Muhammad Rifai

Integrasi Etnomatematik Budaya Pohamba-Hamba (Gotong Royong) pada Pembuatan Talang Poromu (Talang Persatuan) pada Masyarakat Adat Buton Kota Baubau

Oleh: Sardin, Amaluddin 
Eksplorasi Etnomatematika dalam Adat Perhitungan Mahar Pernikahan Masyarakat Buton

Oleh: Wa Ode Irma Rahmawati, La Eru Ugi, Herno, Artati Iriana

Eksplorasi Etnomatematika Rumah Adat Masyarakat Buton

Oleh: Herno

Analisis Kesalahan Siswa pada Pengoperasian Perkalian Bersusun pada Kelas IV SD Negeri 2 Baubau Ditinjau Dari Gaya Kognitif Siswa

Oleh: Rismayani Armin, Artati Iriana 
La Eru Ugi, Herlawan

\title{
ANALISIS KESALAHAN SISWA DALAM MENYELESAIKAN SOAL-SOAL OPERASI HITUNG BILANGAN BULAT DAN ALTERNATIF PEMECAHANNYA DITINJAU DARI GAYA KOGNITIF SISWA KELAS IV SD NEGERI 1 KATOBENGKE KOTA BAUBAU
}

\author{
La Eru Ugi ${ }^{1)}$, Herlawan ${ }^{2)}$ \\ Pendidikan Matematika FKIP Unidayan Baubau ${ }^{1), 2)}$ \\ laeru@ rocketmail.com ${ }^{1)}$
}

\begin{abstract}
Abstrak
Tujuan penelitian ini adalah untuk (1) Mengidentifikasi dan menganalisis kesalahan-kesalahan yang dilakukan siswa dalam menyelesaikan soal-soal operasi hitung bilangan bulat ditinjau dari gaya kognitif, (2) Mengetahui faktor dominan terjadinya kesalahan yang dilakukan siswa dalam menyelesaikan soal-soal operasi hitung bilangan bulat ditinjau dari gaya kognitif, (3) Mengetahui alternatif pemecahan yang baik untuk memperbaiki kesalahan yang dilakukan siswa dalam menyelesaikan soal-soal operasi hitung bilangan bulat di kelas IV SD Negeri 1 Katobengke Kota Baubau. Jenis penelitian ini adalah penelitian kualitatif. Strategi penilaian yang digunakan adalah metofe deskripsi kualitatif. Subjek penelitian adalah siswa kelas IV SD Negeri 1 Katobengke Kota Baubau dengan mempertimbangkan nilai ekstrim artinya siswa yang memperoleh nilai tes GEFT yang paling tinggi dan paling rendah pada setiap masing-masing interval skor tes GEFT tersebut dan paling banyak melakukan kesalahan. Tehnik pengumpulan data yaitu: (1) Tes GEFT, (2) Tes diagnostik, (3) Wawancara, dan (4) Alternatif pemecahan tes diagnostik. Analisis data dalam penelitian ini yaitu: (1) Reduksi data, (2) Penyajian data, dan (3) Penarikan kesimpulan. Hasil Penelitian ini menunjukan bahwa: (1) Kesalahan-kesalahan yang dilakukan oleh siswa dalam menyelesaikan soal-soal operasi hitung bilangan bulat ditinjau dari gaya kongnitifnya: pada subjek berkategori gaya kognitif Field Independent (FI) adalah siswa tidak memahami soal, salah membedakan konsep serta salah langkah penyelesaian, dan salah dalam mengoperasikan; pada subjek berkategori gaya kognitif Field Dependent (FD) adalah siswa tidak bisa membedakan tanda/lambang, salah membedakan tanda dalam konsep serta salah langkah penyelesaian, dan salah dalam mengoperasikan. (2) Faktor-faktor yang menyebabkan siswa melakukan kesalahan dalam menyelesaikan soal- soal operasi hitung bilangan bulat ditinjau dari gaya kognitifnya yaitu pada subjek berkategori gaya kognitif Field Independent (FI) dan pada subjek berkategori gaya kognitif Field Dependent (FD) adalah pada kesalahan konsep: tidak bisa membedakan tanda/lambang, tidak bisa menjawab soal; pada kesalahan prinsip: salah membedakan tanda dalam konsep serta salah langkah penyelesaian, salah membuat penyimbolan, salah menempatkan bilangannya, tanda dalam pengoperasian terkadang diabaikan karena bingung; dan pada kesalahan operasi: salah mengoperasikan, proses pengerjaan tidak teratur, pengerjaan singkat, dan hasil akhir salah. (3) Alternatif pemecahan yang dinilai baik untuk memperbaiki kesalahan dalam menyelesaikan soal-soal operasi hitung bilangan bulat adalah dengan menggunakan media berupa alat peraga, alat peraga disini biasanya dengan menggunakan garis bilangan.
\end{abstract}

Kata kunci: analisis kesalahan, operasi hitung bilangan bulat, alternatif pemecahan, gaya kognitif, field independent (FI), field dependent (FD)

\section{Abstract}

Objectives of this research were 1) to identify and analyze errors made by students in solving problem of Integers Calculation Operation seen by cognitive style; 2) to find out the dominant factors of the occur of error done by students in solving problem of Integers Calculation Operation seen by cognitive style; and 3) to find out the good solution alternative to fix students' error in solving problem of Integers Calculation Operation at grade IV of SD Negeri 1 Katobengke of Baubau town. Type of this research was qualitative research. Strategy of assessment used was qualitative descriptive method. Subject of this research was grade IV students of SD Negeri 1 Katobengke of Baubau town with considering extreme score, which meant students who got the highest and the lowest GEFT test score on every GEFT test score interval and the most mistake the students did. Techniques of data collection were: 1) GEFT test; 2) diagnostic test; 3) interview; and 4) solution alternative of diagnostic test. Data analyses in this research were 1) data reduction; 2) data display; and 3) deducing. Research outcome indicated that: 1) errors that did by students in solving problem of Integers Calculation Operation seen 
La Eru Ugi, Herlawan

by cognitive style: at subject categorized cognitive style of Field Independent (FI) was students did not understand the problem, was wrong to differ concept, was wrong in step of solution, and was wrong in operating; at subject categorized Field Dependent (FD) was students could not differ symbol/sign, was wrong to differ sign in concept, was wrong in step of solution, and was wrong in operating; 2) factors causing students did error in solving problems of Integers Calculation Operation seen by cognitive style was at subject categorized cognitive style of Field Independent (FI) and Field Dependent (FD) was on concept errors: could not differ symbol/sign and could not answer the questions; on principle errors: incorrect to differ sign in concept and steps of solution, incorrect to make symbol, incorrect in placing numbers, sign in operation was sometimes ignored because of confusedness, and on operation errors: incorrect to operate, working process was not organized, short working, and incorrect final result; and 3) solution alternative which was considered good to fix errors in solving problems of Integers Calculation Operation was with using media, such as visual aid, in which this visual aid usually used number line.

Keywords: error analysis, calculation operation of Integers, solution alternative, cognitive style, Field Independent (FI), Field Dependent (FD)

\section{PENDAHULUAN}

$\begin{array}{crr}\text { Dalam } & \text { kehidupan } & \text { sehari-hari kita } \\ \text { menghadapi } & \text { berbagai } & \text { permasalahan. }\end{array}$ Permasalahan yang terjadi menuntut kita untuk dapat memecahkannya. Permasalahanpermasalahan yang terjadi sebagian permasalahan matematis, sehingga menuntut kita untuk dapat memiliki kemampuan dalam matematika. Matematika mempunyai peranan yang cukup besar dalam memberikan berbagai kemampuan berpikir dan kemampuan memecahkan masalah dalam kehidupan seharihari. Ini berarti matematika sangat dibutuhkan dalam kehidupan sehari-hari sehingga kita dapat memcahkan masalah khususnya masalah matematis. Salah satu cara untuk meningkatkan kemampuan matematika adalah melalui dunia pendidikan.

Pendidikan sebagai modal pembangunan dituntuk untuk semakin berperan aktif dalam meningkatkan dan mengembangkan kualitas sumber daya manusia, apalagi dengan adanya globalisasi dan dihadapkannya dengan Masyarakat Ekonomi Asean (MEA), generasi muda harus siap terhadap berbagai perubahan keadaan. Pelajaran matematika sebagai salah satu ilmu dasar yang memiliki nilai esensial yang dapat diterapkan diberbagai bidang kehidupan. Pola pikir matematika juga menjadi sebuah hal penting dalam perkembangan ilmu pengetahuan. Begitu pentingnya matematika tetapi kurang dibarengi dengan semangat peserta didik dalam memperlajari matematika. Dimana mata pelajaran matematika di pandang sebagai pelajaran yang sulit sehingga peserta didik menganggap pelajaran matematika sebagai momok dan pelajaran yang harus dihindari. Meskipun demikian, semua orang harus mempelajari matematika karena merupakan sarana untuk memecahkan masalah kehidupan sehari-hari. Pemecahan masalah merupakan bagian yang sangat penting dalam pelajaran matematika.

Dalam dunia pendidikan Indonesia, mata pelajaran matematika mulai diajarkan sejak kelas satu pada tingkat Sekolah Dasar (SD). Salah satu materi yang dipelajari pada tingkat SD adalah bilangan bulat. Materi bilangan bulat meliputi konsep bilangan bulat dan operasi hitung bilangan bulat, yaitu operasi penjumlahan, pengurangan, perkalian dan pembagian. Operasi hitung bilangan bulat sangat penting dipelajari oleh peserta didik karena merupakan dasar dalam operasi hitung bilangan pada materi matematika. Selain itu, operasi bilangan bulat sangat berkaitan erat dengan kehidupan nyata, sehinga untul lebih mudah menanamkan konsep dalam memperlajari matematika perlu dikaitkan dengan kehidupan nyaata peserta didik. Penguasaan konsep dalam pembelajaran matematika merupakan hal yang sangat penting. Dalam pembelajaran matematika, keterkaitan antara konsep-konsep matematika dengan pengalalaman anak sehari-hari sangat penting dilakukan agar konsep matematika yang dipelajari menjadi lebih mudah dipahami dan dapat diaplikasikan dalam kehidupan sehari- hari. Dengan penguasaan konsep yang baik pada peserta didik dan dapat diaplikasikan pada kehidupannya nyata akan membuat peserta didik akan marasa senang belajar matematika dan tidak menganggap pelajaran matematika sebagai pelajaran yang sulit.

Shadiq \& Ini (2006) tugas utama seorang guru matematika adalah membantu siswanya mendapatkan informasi, ide-ide, keterampilanketerampilan, nilai-nilai, dan cara-cara berpikir serta cara-cara mengemukakan pendapat. Peserta didik yang memiliki ide-ide atau keterampilan- 
La Eru Ugi, Herlawan

keterampilan yang baik akan belajar memecahkan suatu permasalahannya. Tugas yang paling utama bagi seorang guru matematika SD adalah membimbing para siswa tentang bagaimana belajar yang sesungguhnya serta bagaimana belajar memecahkan masalah sehingga hal-hal tersebut dapat digunakan dalam kehidupannya. Selain itu, tugas guru dalam proses pembelajaran memperhatikan gaya kognitif siswa sehingga dapat membantu siswa untuk mencapai tujuan pembelajaran secara maksimal. Namun kenyataannya, guru jarang memperhatikan gaya kognitif siswa dalam proses pembelajaran di kelas bahkan ada guru tidak pernah memperhatikan gaya kognitif siswa, besar kemungkinan mengakibatkan siswa mengalami kesulitan dalam memproses dan mengorganisasikan informasi, sehingga berdampak pada hasil pembelajaran yang dicapai tidak maksimal.

Berdasarkan wawancara penulis dengan Guru serta beberapa siswa kelas IV SD Negeri 1 Katobengke ditemukan sebagian besar siswa kelas IV kurang memahami konsep operasi hitung bilangan bulat terutama penggunaan tanda arah dan tan operasi. Hal ini berdampak pada kemampuan matematika yang dimiliki siswa masih rendah yang dapat dilihat dari kurangnya penguasaan siswa terhadap materi operasi hitung bilangan bulat. Berdasarkan informasi guru matematika SD Negeri 1 Katobengke, ratarata nilai siswa pada materi bilangan bulat termasuk rendah. Siswa sering melakukan kesalahan dalam menyelesaikan soal-soal tentang operasi hitung bilangan bulat.

Permasalahan dalam Pembelajaran Bilangan Bulat di SD cukup banyak ragam permasalahannya, seperti: a) Penggunaan alat peraga atau garis bilangan yang menyimpang dari prinsip kerjanya; b) Salah penafsiran bentuk $a+(-b)$ sebagai $a-b$ atau $a-(-b)$ sebagai $a+b$; c) Masih banyak para guru dan siswa yang tidak dapat membedakan antara tanda $+/-$ sebagai operasi hitung dengan tanda +/sebagai jenis suatu bilangan; d) Kurangan tepatnya memberikan pengertian bilangan bulat; e) Sulitnya memberikan penjelasan bagaimana melakukan operasi hitung pada bilangan bulat secara konkret maupun secara abstrak (tanpa menggunakan alat bantu).

Jamaris (2013, p.186), tahap belajar matematika secara konkret dilakukan dengan cara memanipulasi objek atau dengan kata lain, belajar matematika dengan jalan hands on activities with specially designed manipulative: cubes artibute block, card desk, chips, dan lainlain. Pada tahap siswa SD mereka dapat bernalar secara logis sejauh penalaran itu dapat diaplikasikan pada contoh-contoh spesifik atau konkret. Siswa belum mampu berfikir formal karena pola pikir masih terkait dengan bendabenda konkret. Siswa baru mampu mengingat definisi yang telah ada dan mengungkapkan kembali, tetapi belum mampu untuk merumuskan sendiri definisi-definisi tersebut secara cepat, belum menguasai symbol verbal dan ide-ide abstrak. Pembelajaran matematika pada jenjang SD hendaknya disesuaikan dengan karakterikstik siswa dan tujuan belajar matematika di SD sehingga belajar matematika menjadi bermakna bagi kehidupan siswa.

Hujodo dalam Ulifa (2014, p.124) menyatakan bahwa matematika berkenaan dengan ide-ide atau konsep-konsep abstrak yang tersusun secara hirarkis dan penalarannya deduktif. Dalam proses pembelajaran. Siswa yang mangalami kesulitan belajar akan berakibat pada terjadinya kesalahan dalam menyelesaikan soal-soal matematika. Kesalahan yang dilalukan oleh siswa dalam proses pembelajaran matematika tidak semua siswa selalu berhasil mencapai tujuan pembelajaran. Siswa yang mengalami kesulitan belajar akan berakibat pada terjadinya kesalahan dalam menyelesaikan soalsoal matematika. Kesalahan yang dilakukan oleh siswa dalam menyelesaikan soal-soal matematika dapat dilihat dari berbagai hal. Soedjadi dalam Ulifa (2014, p.125) kesalahankesalahan yang dilakukan siswa dapat diklasifikasikan beberapa bentuk kesalahan, diantarannya (1) kesalahan procedural, yaitu dalam menggunakan algoritma, misalnya kesalahan melaukan operasi hitung, (2) kesalahan dalam mengorganisasikan data, misalnya kesalahan menuliskan apa yang diketahui, apa yang ditanyakan dari soal, (3) kesalahan mengurutkan, mengelompokan dan menyajikan data, (4) kesalahan dalam memanfaatkan symbol, table dan grafik yang memuat suatu informasi, (5) kesalahan dalam melakukan manipulasi secara matematis, sifat-sifat dalam menyelesaikan soal, dan (6) kesalahan dalam menarik kesimpulan, misalnya kesalahan dalam menuliskan kesimpulan.

Gaya kognitif siswa merupakan salah satu yang mempengaruhi siswa dalam menyelesaikan masalah. Ada siswa yang jika diberikan soal latihan dengan cepat mengacukan tangannya untuk segera menyelesaikan walaupun jawabannya cenderung kurang tepat, ada pula 
La Eru Ugi, Herlawan

siswa yang terlebih dahulu memperhatikan maksud soal kemudian meyelesaikan dengan penuh ketelitian. Ketika siswa memiliki gaya kognitif yang berbeda maka cara menyelesaikan masalah juga berbeda, sehingga perbedaan itu juga memicu perbedaan kreativitas mereka. Salah satu gaya kognitif siswa adalah field independent (FI) dan field dependent (FD). Woolfolk dalam Hamzah (2012: 187), bahwa banyak variasi gaya kognitif yang banyak diminati para pendidik, dan mereka membedakan gaya kognitif berdasarkan dimensi perbedaan aspek psikologis yang terdiri dari Field Independent (FI) dan Field Dependent (FD). FI dan FD adalah merupakan gaya kognitif yang mencerminkan cara analisis seseoarang dalam berinteraksi dengan lingkungan.

Berdasarkan latar belakang di atas, peneliti berusaha untuk menganalisis kesalahankesalahan yang dilakukan siswa dalam menyelesaikan operasi bilangan bulat dan alternatif pemecahannya ditinjau dari gaya kognitif siswa SD Negeri 1 Katobengke Kota Baubau.

Sehubungan dengan uraian diatas, maka rumusan masalah dalam penelitian ini, yaitu: 1) Kesalahan-kesalahan apa dilakukan oleh siswa kelas IV SD Negeri 1 Katobengke Kota Baubau dalam menyelesaikan soal-soal operasi hitung bilangan bulat ditinjau dari gaya kongnitifnya?; 2) Faktor-faktor yang menyebabkan siswa melakukan kesalahan dalam menyelesaikan soalsoal operasi hitung bilangan bulat di Kelas IV SD Negeri 1 Katobengke Kota Baubau ditinjau dari gaya kognitifnya?; dan 3) Bagaimana alternatif pemecahan yang dinilai baik untuk memperbaiki kesalahan dalam menyelesaikan soal-soal operasi hitung bilangan bulat di Kelas IV SD Negeri 1 Katobengke Kota Baubau?.

Tujuan penelitian ini adalah untuk (1) Mengidentifikasi dan menganalisis kesalahankesalahan yang dilakukan siswa dalam menyelesaikan soal-soal operasi hitung bilangan bulat di kelas IV SD Negeri 1 Katobengke Kota Baubau ditinjau dari gaya kognitif, (2) Mengetahui factor dominan terjadinya kesalahan yang dilakukan siswa dalam menyelesaikan soal-soal operasi hitung bilangan bulat di kelas IV SD Negeri 1 Katobengke Kota Baubau ditinjau dari gaya kognitif, (3) Mengetahui alternatif pemecahan yang baik untuk memperbaiki kesalahan yang dilakukan siswa dalam menyelesaikan soal-soal operasi hitung bilangan bulat di kelas IV SD Negeri 1 Katobengke Kota Baubau.

\section{METODE PENELITIAN}

\section{Jenis dan Desain Penelitian}

Penelitian ini adalah kualitatif. Strategi penelitian yang digunakan adalah metode deskripsi kualitatif. Penelitian deskriptif adalah penelitian yang memberikan gambaran dari suatu gejala yang ada dan menjawab pertanyaanpertanyaan yang ada yang berhubungan dengan status (keadaan) subyek penelitian pada saat tertentu. Data yang diperoleh akan dideskripsikan atau diuraikan kembali kemudian dianalisis. Adapun rancangan yang digunakan dalam penelitian ini sebagai berikut: 1) Observasi; 2) Menetapkan kelas yaitu kelas IV SD dengan pertimbangan bahwa siswa kelas IV sudah mendapat materi ajar operasi hitung bilangan bulat; 3) Pemberian tes Group Embedded Figures Test (GEFT) kepada kelas yang ditetapkan; 4) Menganalisias hasil tes GEFT yang telah diberikan kepada siswa; 5) Mengelompokkan siswa ditinjau dari hasil tes GEFT; 6) Pemberian tes diagnostik; 7) Wawancara; dan 8) Pemberian alternatif pemecahan.

\section{Lokasi Penelitian}

Penelitian iniakan dilaksanakan di KelasIV SD Negeri 1 Katobengke Kota Baubau.

\section{Subjek Penelitian}

Subjek dalam penelitian ini adalah siswa KelasIV SD Negeri 1 Katobengke Kota Baubau. Penelitian akan dilaksanakan di SD Negeri 1 Katobengke Kota Baubau masing-masing diambil 2 kelompok siswa kelas IV sebagai subjek penelitian, yang terdiri dari 2 siswa subjek Field Independent (FI) dan 2 siswa subjek Field Dependent (FD). Dalam menentukan ke-4 subjekyaitu masing-masing 2 subjek FI dan 2 subjek FD tersebut diambil berdasarkan hasil tes GEFT. Skor dengan gaya kognitif $(10 \leq \mathrm{x} \leq 18)$ masuk kategori gaya kognitif $\mathrm{FI}$, dan skor $(0 \leq \mathrm{x}$ $\leq 9)$ dikategorikan memiliki gaya kognitif FD.

Adapun langkah-langkah pemilihan subjek penelitian adalah sebagai berikut: 1) Menetapkan kelas yaitu kelas IV SD tahun pelajaran 2017/2018 dengan pertimbangan bahwa siswa kelas IV sudah mendapat materi ajar operasi hitung bilangan bulat; 2) Pemberian tes GEFT kepada kelas yang telah ditetapkan; 3) Menganalisias hasil tes GEFT yang telah diberikan kepada siswa; 4) Mengelompokkan siswa ditinjau dari hasil tes GEFT. Siswa yang berada pada Field-independent dipilih dengan mengacu pada skor dalam interval $(10 \leq \mathrm{x} \leq 18)$ 
La Eru Ugi, Herlawan

tes GEFT, sedangkan siswa Field-dependent dipilih dengan mengacu pada skor dalam interval $(0 \leq \mathrm{x} \leq 9)$ tes GEFT; 5) Memilih minimal 2 subjek untuk tiap kelompok dengan mempertimbangkan nilai ekstrim artinya siswa yang memperoleh nilai tes GEFT yang paling tinggi dan paling rendah pada setiap masingmasing interval skor tes GEFT tersebut dan paling banyak melakukan kesalahan; 6) Jika masing-masing kelompok terdapat minimal dua subjek yang memenuhi kriteria poin 5, maka calon subjek akan dijadikan subjek penelitian. 7) Jika tidak ditemukan minimal dua subjek pada tiap-tiap kelompok maka akan dilakukan langkah $1,2,3,4,5$, dan 6 . Proses ini berlangsung terus menerus sampai subjek ditemukan sesuai kriteria yang ditetapkan.

\section{Variabel Penelitian}

Variabel yang diamati pada penelitian ini yaitu opersi hitung bilangan bulat. Operasi hitung bilangan bulat adalah suatu fungsi yang mengaitkan antara objek matematika yang satu dengan objek matematika lainnya pada bilangan bulat. Operasi Hitung bilangan bulat pada penelitian ini berupa penjumlahan, pengurangan, perkalian, dan pembagian pada bilangan bulat.

\section{Teknik dan Instrumen pengumpulan Data}

Teknik pengumpulan Data

Teknik pengumpulan data dalam penelitian ini, yaitu: 1) Pemberian Tes GEFT kepada seluruh kelas IV SD yang telah ditetapkan yaitu dengan memilih siswa yang menjadi kelompok FD dan FI. Siswa FI dengan mengacu pada skordalam interval $(10 \leq x \leq 18)$ tes GEFT, sedangkan siswa FD dipilih dengan mengacupada skor dalam interval $(0 \leq x \leq 9)$ tes GEFT. 2) Pemberian tes diagnostik untuk memperoleh data dalam penelitian ini, diberikan tes diagnostik kepada subjek penelitian untuk mengetahui kemampuan siswa dalam menyelesaikan operasi hitung bilangan bulat. Kemudian hasil pekerjaan siswa dari tes diagnostik tersebut dianalisis berdasarkan jenisjenis kesalahan yang dilakukan siswa. 3) Wawancara dilakukan dengan siswa yang banyak melakukan kesalahan. Wawancara dengan siswa ini dilakukan untuk menelusuri lebih lanjut kesalahan siswa dalam mempelajari matematika khususnya dalam menyelesaikan soal-soal operasi hitung bilangan bulat. Dalam wawancara ini pula akan diketahui bagaimana proses berpikir siswa dalam menyelesaikan soal- soal operasi hitung bilangan bulat, faktor-faktor apa saja yang menyebabkan terjadinya kesalahan siswa dalam menyelesaikan soal-soal operasi hinting bilangan bulat, agar dapat peneliti berikan alternatif pemecahan yang dinilai baik untuk memperbaiki kesalahan-kesalahan tersebut dalam menyelesaikan soal-soal operasi hitung bilangan bulat di kelas IV SD Negeri 1 Katobengke Kota Baubau. 4) Pemberian alternatif pemecahan bertujuan untuk memberikan pemahaman kepada siswa tentang cara yang dinilai baik dan mudah dalam menyelesaikan soal-soal operasi hitung bilangan bulat secara klasikal berdasarkan banyaknya kesalahan yang dilakukan oleh siswa.

Adapun langkah-langkah pemberian alternatif pemecahan adalah sebagai berikut: 1) Memberikan pemahaman konsep dasar tentang operasi bilangan bulat. 2) Memberikan pemahaman tentang operasi hitung bilangan bulat, bahwa operasi hitung bilangan yang meliputi penjumlahan, pengurangan, perkalian dan pembagian mempunyai tingkatan dalam urutan pengerjaanya.

\section{Instrumen Penelitian}

Instrumen utama dalam penelitian ini adalah peneliti sendiri, serta instrumen pendukung antara lain: 1) Tes GEFT (Group Embedded Figures Test). Group Embedded Figures Test (GEFT), adalah alat ukur yang dikembangkan untuk menggolongkan seseorang apakah seseorang termasuk gaya kognitif FI atau FD. Tes ini dikembangkan oleh Witkin dengan teks asli berbahasa inggris dan telah dialihbahasakan ke dalam Bahasa Indonesia oleh Degeng, Dosen Program Pascasarjana Jurusan Teknologi Pendidikan Universitas Negeri Malang (Amin, 2010, p.117). 2) Tes I (tes diagnostik) yang dimaksudkan untuk memperoleh data dan bahan pengamatan mengenai kesalahan siswa dalam menyelesaikan operasi bilangan bulat. 3) Pedoman wawancara yang dibuat berdasarkan respon siswa terhadap tes diagnostik yang diberikan yang bertujuan untuk memperoleh data secara mendalam tentang kesalahan-kesalahan yang dilakukan siswa, yang tidak dapat dideteksi dengan menggunakan tes diagnostik. 4) Srategi guru pada pemecahan soal tes diagnostik yang digunakan untuk memberikan pemahaman kepada siswa tentang penyelesaian-penyelesaian soal yang baik guna mengurangi kesalahankesalahan yang dilakukan siswa dalam menyelesaikan soal-soal bilangan bulat Tes II (tes setelah pemberian strategi guru pada 
La Eru Ugi, Herlawan

pemecahan soal) yang digunakan untuk melihat bahwa strategi guru pada pemecahan tes diagnostik dinilai berhasil.

\section{Teknik Analisis Data}

Analisis data penelitian ini terdiri dari tiga alur kegiatan yaitu reduksi data, penyajian data, serta verifikasi dan penarikan kesimpulan.

Reduksi data

Reduksi data adalah pemilihan dan penyederhanaan data. Kegiatan ini dilakukan untuk menghindari penumpukan data atau informasi yang sama dari siswa.

Penyajian data

Data yang disajikan berupa jenis-jenis kesalahan yang dilakukan siawa dalam menyelesaikan opersi hitung bilangan bulat ditinjau dari gaya kognitif faktor-faktor penyebabnya serta strategi mengatasi kesalahankesalahan tersebut.

Verifikasi data dan penarikan kesimpulan

Verifikasi data penarikan kesimpulan dilakukan selama kegiatan analisis berlangsung sehingga diperoleh suatu kesimpulan yang final. Penarikan kesimpulan dilakukan berdasarkan analisis terhadap data yang telah dikumpulkan baik melalui tes, maupun wawancara terhadap siswa. Hal ini dilakukan dengan cara membandingkan hasil pekerjaan siswa dengan hasil wawancara dengan siswa, sehingga dapat ditarik kesimpulan yang benar tentang jenis-jenis kesalahan, penyebab terjadinya kesalahan serta dapat menemukan alternatif mengatasi kesalahan-kesalahan yang dilakukan siswa.

\section{HASIL PENELITIAN DAN PEMBAHASAN}

\section{Deskripsi Data}

Tahapan pertama yang dilakukan dalam proses penelitian tahap persiapan adalah observasi lapangan. Observasi lapangan bertujuan untuk menentukan calon subjek penelitian. Subjek dalam penelitian ini adalah siswa kelas IV SD Negeri 1 Katobengke Kota Baubau. Bagian ini memaparkan hasil-hasil yang diperoleh dalam penelitian tentang kesalahan siswa dalam menyelesaikan soal-soal operasi hitung dan pembahasannya berdasarkan gaya kognitif siswa. Pengumpulan data pada penelitian ini digunakan tes gaya kognitif siswa dan masalah matematika, serta pedoman wawancara. Hasil tes gaya kognitif siswa pada penelitian ini diperlukan untuk mengelompokkan siswa berdasarkan gaya kognitif yang dimilikinya, yaitu kelompok siswa dengan gaya kognitif fieldindependent (FI) dan kelompok siswa dengan gaya kognitif field-dependent (FD), pemberian Tes GEFT pada siswa kelas IV SD Negeri 1Katobengke kemudian peneliti menganalisis hasil tes GEFT yang telah diberikan kepada siswa kelas IV tersebut. Siswa dikelompokkan berdasarkan hasil tes GEFT. Siswa yang berada pada Field-independent dipilih dengan mengacu pada skor dalam interval $(10 \leq \mathrm{x} \leq 18)$ tes GEFT, sedangkan siswa Field-dependent dipilih dengan mengacu pada skor dalam interval $(0 \leq \mathrm{x} \leq 9)$ tes GEFT. Kemudian Peneliti Memilih minimal 2 subjek untuk tiap kelompok dengan mempertimbangkan nilai ekstrim artinya siswa yang memperoleh nilai tes GEFT yang paling tinggi dan paling rendah pada setiap masingmasing interval skor tes GEFT tersebut dan paling banyak melakukan kesalahan. Data gaya kognitif siswa pada penelitian ini diperoleh dari hasil tes gaya kognitif pada siswa kelas IV di SD Negeri 1 Katobengke. Berdasarkan hasil tes gaya kognitif tersebut diperoleh data seperti pada Tabel berikut:

Tabel 1. Deskripsi Gaya Kognitif Berdasarkan Kelas

\begin{tabular}{cccc}
\hline Kelas & FI & FD & Jumlah \\
\hline IV & 9 & 15 & 24 \\
\hline
\end{tabular}

Dari hasil pengelompokkan tersebut diambil 4 siswa yakni 2 siswa FI dan 2 siswa FD masingmasing kelompok dijadikan subjek penelitian berdasarkan pertimbangan bahwa siswa tersebut disajikan dalam Tabel berikut:

Tabel 2. Siswa Kelas IV Yang Terpilih Menjadi Subjek Penelitian

\begin{tabular}{ccc}
\hline $\begin{array}{c}\text { Kode Siswa } \\
(\text { Subjek })\end{array}$ & $\begin{array}{c}\text { Jenis } \\
\text { Kelamin }\end{array}$ & Kelompok \\
\hline FAL & Laki-laki & FI \\
\hline ARF & Laki-laki & FI \\
\hline MNR & Laki-laki & FD \\
\hline WEG & Perempuan & FD \\
\hline
\end{tabular}

\section{Pemberian Tes I (Tes Diagnostik)}

Pemberian Tes I (Tes Diagnostik) dilaksanakan pada hari Senin 2 April 2018 pada seluruh Siswa kelas IV SD Negeri 1 Katobengke sebanyak 24 Siswa. Pemberian Tes I (Tes Diagnostik) diawasi oleh Peneliti dan Guru kelas IV untuk menjaga keobjektifan jawaban siswa. 
La Eru Ugi, Herlawan

Hasil Tes I (Tes Diagnostik) selanjutnya diperiksa dan dianalisis oleh peneliti.

Deskripsi Kesalahan Siswa dalam Menyelesaikan Soal-Soal Operasi Hitung Bilangan Bulat pada Tes I (Tes Diagnostik) dan Penyebabnya

Siswa yang terpilih sebagai subjek penelitian diwawancara untuk memperoleh lebih banyak informasi mengenai kesalahan-kesalahan yang dilakukan pada soal-soal operasi hitung bilangan bulat. Hasil petikan wawancara diselaraskan dengan hasil tes diagnostik subjek sehingga bisa diketahui penyebab terjadinya kesalahan tersebut dan menemukan strategi yang dinilai baik untuk memeperbaiki kesalahan-kesalahan tersebut. Deskripsi kesalahan siswa dalam menyelesaikan soal-soal operasi hitung bilangan bulat pada kategori siswa FI (Field independent).

Hasil Tes I (Tes Diagnostik) Subjek Kategori dengan Gaya Kognitif Field-Independent (FI)

\section{Subjek FAL $\left(\boldsymbol{F I}_{1}\right)$}

Penggalan jawaban tes diagnostik pada soal nomor 2

$$
2-2+5-7 \quad 2+5=7 \text { cance bih tingi positif dari padanegat inf jadi }-2+5=77
$$

Gambar 1. Penggalan Jawaban Tes I (Tes Diagnostik) pada Soal Nomor 2 Inisial FAL

Siswa yang bersangkutan dalam menjawab soal tersebut sudah mengetahui konsep dalam soal, namun salah dalam menyelesaikan soal yang dikategorikan salah prinsip kerja dengan mengganggap positif lebih tinggi yang hasilnya juga akan positif tetapi dalam penentuan hasil akhirnya yaitu kategori operasi juga salah karena bilangannya langsung dijumlahkan tanpa memperhatikan positif dan negatifnya yang hasil akhirnya adalah 7 . Untuk mengetahui penyebab terjadinya kesalahan tersebut, berikut petikan wawancaranya:

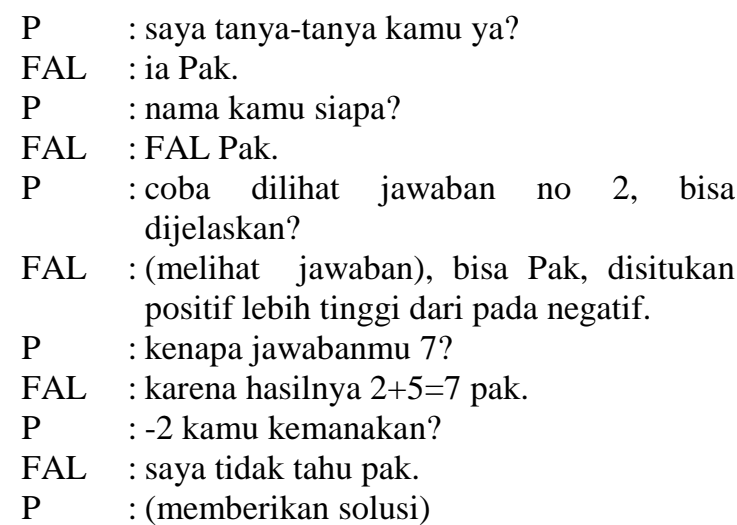

Dari petikan wawancara di atas siswa mengetahui konsep tetapi salah pada prinsip dan operasinya sehingga jawaban akhirnya masih keliru yang seharusnya jawaban akhir adalah 3 , subjek mengerjakan hasil akhir adalah 7, disitu kita lihat kalau pemahaman konsep operasi penjumlahan bilangan bulat positif dengan bilangan bulat negatif subjek masih harus dipermantap terutama tentang penetapan simbol atau tanda arah.

Berdasarkan hasil data jawaban tertulis dan wawancara di atas, maka peneliti membuat triangulasi data kesimpulan bahwa data yang diperoleh dari subjek FAL untuk soal nomor 2 adalah valid.

Tabel 3. Kategori Kesalahan dan Penyebab Kesalahan dalam Menyelesaikan Soal pada Subjek Berkategori Gaya Kognitif Field Independent (FI-FAL) Soal Nomor 2

\begin{tabular}{|c|c|c|}
\hline $\begin{array}{l}\text { Kategori } \\
\text { kesalahan }\end{array}$ & $\begin{array}{l}\text { Indikator } \\
\text { kesalahan }\end{array}$ & $\begin{array}{l}\text { Penyebab } \\
\text { kesalahan }\end{array}$ \\
\hline Kesalahan & tidak bisa bedakan & bisa membedakan \\
\hline konsep & tanda/rumus & tanda/lambang \\
\hline Kesalahan & 1. paham konsep & salah membedakan \\
\hline prinsip & 2. salah langkah & $\begin{array}{l}\text { konsep serta salah } \\
\text { langkah } \\
\text { penyelesaian }\end{array}$ \\
\hline $\begin{array}{l}\text { Kesalahan } \\
\text { operasi }\end{array}$ & $\begin{array}{l}\text { salah } \\
\text { mengoperasikan }\end{array}$ & $\begin{array}{l}\text { salah } \\
\text { mengoperasikan }\end{array}$ \\
\hline
\end{tabular}

Penggalan jawaban tes diagnostik soal nomor 4

$$
4.2-5=300-00000=000
$$

Gambar 2. Penggalan Jawaban Tes I (Tes

Diagnostik) pada Soal Nomor 4 Inisial FAL

Siswa yang bersangkutan dalam menjawab soal tersebut sudah mengetahui konsep dalam soal, namun salah dalam menyelesaikan soal yang dikategorikan salah prinsip kerja dengan membuat bulatan-bulatan tetapi prinsip pengurangan jika yang dikurangkan lebiih besar hasilnya bagaimana sehingga dalam penentuan hasil akhirnya yaitu kategori operasi juga salah karena bilangannya asal dikurangkan yang hasil akhirnya adalah 3 . Untuk mengetahui penyebab terjadinya kesalahan tersebut, berikut petikan wawancaranya:

P : : Sekarang lihat lagi jawabanmu nomor 4

FAL : iya Pak (melihat kertas jawaban). 
La Eru Ugi, Herlawan

$\mathrm{P}$ : coba lihat pekerjaanmu menggunakan bulatan-bulatan

FAL : (memperhatikan).

P : coba jelaskan

FAL : iya Pak, ini dua bulatan mewakili angka dua dan lima bulatan mewakili angka 5 pak

$\mathrm{P} \quad$ : terus penyelesaiannya bagaimana?

FAL : tinggal dikurangkan pak. Yang lima kurang dua.

$\mathrm{P} \quad$ : tidak terbalik?

FAL : (diam).

P : kebalikkan?

FAL : iya Pak (melihat kertas jawaban).

$\mathrm{P} \quad$ : (memberikan solusi)

Dari petikan wawancara di atas siswa mengetahui konsep tetapi salah pada prinsip dan operasinya sehingga jawaban akhirnya masih keliru yang seharusnya jawaban akhir adalah negatif 3 , subjek mengerjakan hasil akhir adalah 3, disitu kita lihat kalau pemahaman konsep operasi penjumlahan bilangan bulat positif dengan bilangan bulat negatif subjek masih harus dipermantap terutama tentang penetapan simbol atau tanda arah.

Berdasarkan hasil data jawaban tertulis dan wawancara di atas, maka peneliti membuat triangulasi data kesimpulan bahwa data yang diperoleh dari subjek FAL untuk soal nomor 4 adalah valid.

Tabel 4. Kategori Kesalahan dan Penyebab Kesalahan dalam Menyelesaikan Soal pada Subjek Berkategori Gaya Kognitif Field Independent (FI-FAL) Soal Nomor 4

\begin{tabular}{|c|c|c|}
\hline $\begin{array}{l}\text { Kategori } \\
\text { kesalahan }\end{array}$ & $\begin{array}{l}\text { Indikator } \\
\text { kesalahan }\end{array}$ & $\begin{array}{l}\text { Penyebab } \\
\text { kesalahan }\end{array}$ \\
\hline $\begin{array}{l}\text { Kesalahan } \\
\text { konsen }\end{array}$ & tidak bisa bedakan & bisa membedakan \\
\hline Kesalahan & 1. paham konsep & salah membedakan \\
\hline prinsip & 2. salah langkah & $\begin{array}{l}\text { konsep serta salah } \\
\text { langkah } \\
\text { penyelesaian }\end{array}$ \\
\hline $\begin{array}{l}\text { Kesalahan } \\
\text { operasi }\end{array}$ & $\begin{array}{l}\text { salah } \\
\text { mengoperasikan }\end{array}$ & $\begin{array}{l}\text { salah } \\
\text { mengoperasikan }\end{array}$ \\
\hline
\end{tabular}

Penggalan jawaban tes diagnostik soal nomor 5

$$
5-2-(-5)=-3 \quad 2-5-3-2-(-5)=-3
$$

Gambar 3. Penggalan Jawaban Tes I (Tes Diagnostik) pada Soal Nomor 5 Inisial FAL
Jawaban pada soal ini siswa paham konsep pengurangan bilangan bulat, namun dalam menggunakan prinsip siswa FAL menganggap -5 sama dengan 5 ini dapat dilihat pada langkah selanjutnya tanda negatif dihilangkan. Kemudian pada penggunaan operasinya siswa ini juga melakukan kesalah karena hasil akhir yang dituliskan adalah -3. Untuk mengetahui penyebab terjadinya kesalahan tersebut, berikut petikan wawancaranya:

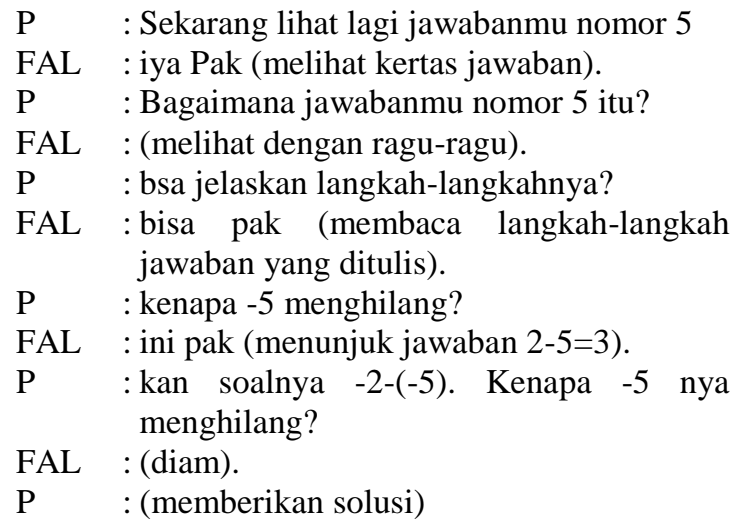

Dari petikan wawancara di atas diketahui bahwa subjek belum sepenuhnya memahami konsep operasi pengurangan bilangan bulat negatif dengan bilangan negatif sehingga pada saat penerapan prinsip dan operasinya subjek masih salah dalam menyelesaikan hasil akhir dikarenakan subjek bingung dengan tanda yang melekat pada soal yakni -5 .

Berdasarkan hasil data jawaban tertulis dan wawancara di atas, maka peneliti membuat triangulasi data kesimpulan bahwa data yang diperoleh dari subjek FAL untuk soal nomor 5 adalah valid.

Tabel 5. Kategori Kesalahan dan Penyebab Kesalahan dalam Menyelesaikan Soal pada Subjek Berkategori Gaya Kognitif Field Independent (FI-FAL) Soal Nomor 5

\begin{tabular}{|c|c|c|}
\hline $\begin{array}{l}\text { Kategori } \\
\text { kesalahan }\end{array}$ & $\begin{array}{l}\text { Indikator } \\
\text { kesalahan }\end{array}$ & $\begin{array}{l}\text { Penyebab } \\
\text { kesalahan }\end{array}$ \\
\hline Kesalahan & tidak bisa bedakan & bisa membedakan \\
\hline konsep & tanda/rumus & tanda/lambang \\
\hline Kesalahan & 1. paham konsep & salah membedakan \\
\hline prinsip & 2. salah langkah & $\begin{array}{l}\text { tanda dalam konsep } \\
\text { serta salah langkah } \\
\text { penyelesaian }\end{array}$ \\
\hline $\begin{array}{l}\text { Kesalahan } \\
\text { operasi }\end{array}$ & $\begin{array}{l}\text { salah } \\
\text { mengoperasikan }\end{array}$ & $\begin{array}{l}\text { salah } \\
\text { mengoperasikan }\end{array}$ \\
\hline
\end{tabular}


La Eru Ugi, Herlawan

Penggalan jawaban tes diagnostik soal nomor 8

$$
84:(-2)=2 \quad 8: 2=2 \quad 4:(-2)=-42
$$

Gambar 4. Penggalan Jawaban Tes I (Tes Diagnostik) pada Soal Nomor 8 Inisial FAL

Jawaban pada soal ini siswa sidah mengetahui konsep pada soal, namun pada penggunaan prinsip selalu saja tanda negatifnya diabaikan. Ini mengakibatkan pada operasinya juga mengalami kesalahan. Untuk mengetahui penyebab terjadinya kesalahan tersebut, berikut petikan wawancaranya:

$\mathrm{P} \quad$ : Sekarang lihat lagi jawabanmu nomor 8

FAL : iya Pak (melihat kertas jawaban).

$\mathrm{P} \quad$ : kira-kira tahu tidak kesalahan yang kamu buat?

FAL : (diam).

$\mathrm{P} \quad$ : tanda -2 lagi kamu kemanakan?

FAL : (diam).

$\mathrm{P} \quad$ : (memberikan solusi)

Dari petikan wawancara di atas diketahui bahwa siswa mengalami kesalahan lagi pada penggunaan prinsip dan operasinya. Dimana tanda negatifnya dianggapnya tidak perlu, sehingga hasil akhirnya salah.
Berdasarkan hasil data jawaban tertulis dan wawancara di atas, maka peneliti membuat triangulasi data kesimpulan bahwa data yang diperoleh dari subjek FAL untuk soal nomor 8 adalah valid.

Tabel 6. Kategori Kesalahan dan Penyebab Kesalahan dalam Menyelesaikan Soal pada Subjek Berkategori Gaya Kognitif Field Independent (FI-FAL) Soal Nomor 8

\begin{tabular}{|c|c|c|}
\hline $\begin{array}{l}\text { Kategori } \\
\text { kesalahan }\end{array}$ & $\begin{array}{l}\text { Indikator } \\
\text { kesalahan }\end{array}$ & $\begin{array}{l}\text { Penyebab } \\
\text { kesalahan }\end{array}$ \\
\hline $\begin{array}{l}\text { Kesalahan } \\
\text { konsep } \\
\text { Kesalahan } \\
\text { prinsip }\end{array}$ & $\begin{array}{l}\text { tidak bisa bedakan } \\
\text { tanda/rumus } \\
\text { 1. paham konsep } \\
\text { 2. salah langkah }\end{array}$ & $\begin{array}{l}\text { bisa membedakan } \\
\text { tanda/lambang } \\
\text { salah membedakan } \\
\text { tanda dalam konsep } \\
\text { serta salah langkah } \\
\text { penyelesaian }\end{array}$ \\
\hline $\begin{array}{l}\text { Kesalahan } \\
\text { operasi }\end{array}$ & $\begin{array}{l}\text { salah } \\
\text { mengoperasikan }\end{array}$ & $\begin{array}{l}\text { salah } \\
\text { mengoperasikan }\end{array}$ \\
\hline
\end{tabular}

Tabel 7. Rekapitulasi Kesalahan dan Penyebab Kesalahan dalam Menyelesaikan Soal pada Subjek Berkategori Gaya Kognitif Field Independent (FI) dan Subjek Berkategori Gaya Kognitif Field Dependent (FD) pada Tes I

\begin{tabular}{|c|c|c|c|c|c|}
\hline \multirow{2}{*}{ No. } & \multirow{2}{*}{ Soal } & \multicolumn{2}{|c|}{ Subkek FI } & \multicolumn{2}{|c|}{ Subjek FD } \\
\hline & & FAL & ARF & MNR & WEG \\
\hline 1. & $2+5=\ldots$ & Soal dijawab benar & Soal dijawab benar & Soal dijawab benar & Soal dijawab benar \\
\hline 2. & $-2+5=\ldots$ & $\begin{array}{l}\text { bisa membedakan } \\
\text { tanda/lambang } \\
\text { salah membedakan } \\
\text { konsep serta salah } \\
\text { langkah penyelesaian } \\
\text { salah mengoperasikan }\end{array}$ & Soal dijawab benar & $\begin{array}{l}\text { tidak bisa membedakan } \\
\text { tanda/lambang } \\
\text { salah membedakan tanda } \\
\text { dalam konsep serta salah } \\
\text { langkah penyelesaian } \\
\text { salah mengoperasikan } \\
\end{array}$ & Soal dijawab benar \\
\hline 3. & $-2+(-5)=\ldots$ & Soal dijawab benar & $\begin{array}{l}\text { bisa membedakan } \\
\text { tanda/lambang } \\
\text { salah membedakan tanda } \\
\text { dalam konsep sehingga } \\
\text { ada bilangan yang tidak } \\
\text { diselesaikan serta salah } \\
\text { langkah penyelesaian } \\
\text { salah mengoperasikan }\end{array}$ & $\begin{array}{l}\text { tidak bisa membedakan } \\
\text { tanda/lambang } \\
\text { salah membedakan tanda } \\
\text { dalam konsep serta salah } \\
\text { langkah penyelesaian } \\
\text { salah mengoperasikan }\end{array}$ & $\begin{array}{l}\text { bisa membedakan } \\
\text { tanda/lambang } \\
\text { salah membedakan tanda } \\
\text { dalam konsep serta salah } \\
\text { langkah penyelesaian } \\
\text { salah mengoperasikan }\end{array}$ \\
\hline 4. & $2-5=\ldots$ & $\begin{array}{l}\text { bisa membedakan } \\
\text { tanda/lambang } \\
\text { salah membedakan } \\
\text { konsep serta salah } \\
\text { langkah penyelesaian } \\
\text { salah mengoperasikan }\end{array}$ & $\begin{array}{l}\text { bisa membedakan } \\
\text { tanda/lambang } \\
\text { salah membedakan tanda } \\
\text { dalam konsep sehingga } \\
\text { bilangannya hanya } \\
\text { dibolak-balik serta salah } \\
\text { langkah penyelesaian } \\
\text { salah mengoperasikan } \\
\end{array}$ & $\begin{array}{l}\text { tidak bisa membedakan } \\
\text { tanda/lambang } \\
\text { salah membedakan tanda } \\
\text { dalam konsep serta salah } \\
\text { langkah penyelesaian } \\
\text { salah mengoperasikan }\end{array}$ & $\begin{array}{l}\text { bisa membedakan } \\
\text { tanda/lambang } \\
\text { salah membedakan tanda } \\
\text { dalam konsep serta salah } \\
\text { langkah penyelesaian } \\
\text { salah mengoperasikan }\end{array}$ \\
\hline 5. & $-2-(-5)=\ldots$ & $\begin{array}{l}\text { bisa membedakan } \\
\text { tanda/lambang } \\
\text { salah membedakan tanda }\end{array}$ & $\begin{array}{l}\text { tidak memahami soalnya } \\
\text { Salah konsep dan } \\
\text { langkanya }\end{array}$ & $\begin{array}{l}\text { bisa membedakan } \\
\text { tanda/lambang } \\
\text { salah membedakan tanda }\end{array}$ & $\begin{array}{l}\text { bisa membedakan } \\
\text { tanda/lambang } \\
\text { salah membedakan tanda }\end{array}$ \\
\hline
\end{tabular}


La Eru Ugi, Herlawan

\begin{tabular}{|c|c|c|c|c|c|}
\hline & & $\begin{array}{l}\text { dalam konsep serta salah } \\
\text { langkah penyelesaian } \\
\text { salah mengoperasikan }\end{array}$ & salah mengoperasikan & $\begin{array}{l}\text { dalam konsep serta salah } \\
\text { langkah penyelesaian } \\
\text { salah mengoperasikan }\end{array}$ & $\begin{array}{l}\text { dalam konsep serta salah } \\
\text { langkah penyelesaian } \\
\text { salah mengoperasikan }\end{array}$ \\
\hline 6. & $2 \times(-5)=\ldots$ & Soal dijawab benar & $\begin{array}{l}\text { bisa membedakan } \\
\text { tanda/lambang } \\
\text { salah membedakan tanda } \\
\text { dalam konsep sehingga } \\
\text { arah dalam penyelesaian } \\
\text { salah } \\
\text { salah mengoperasikan }\end{array}$ & $\begin{array}{l}\text { bisa membedakan } \\
\text { tanda/lambang } \\
\text { salah membedakan tanda } \\
\text { dalam konsep serta salah } \\
\text { langkah penyelesaian } \\
\text { salah mengoperasikan }\end{array}$ & $\begin{array}{l}\text { tidak bisa membedakan } \\
\text { tanda/lambang } \\
\text { salah membedakan tanda } \\
\text { dalam konsep serta salah } \\
\text { langkah penyelesaian } \\
\text { salah mengoperasikan }\end{array}$ \\
\hline 7. & $-2 \times(-5)=\ldots$ & Soal dijawab benar & $\begin{array}{l}\text { bisa membedakan } \\
\text { tanda/lambang } \\
\text { salah membedakan tanda } \\
\text { dalam konsep serta salah } \\
\text { langkah penyelesaian } \\
\text { salah mengoperasikan }\end{array}$ & $\begin{array}{l}\text { tidak bisa membedakan } \\
\text { tanda/lambang } \\
\text { salah membedakan tanda } \\
\text { dalam konsep serta salah } \\
\text { langkah penyelesaian } \\
\text { salah mengoperasikan }\end{array}$ & $\begin{array}{l}\text { tidak bisa membedakan } \\
\text { tanda/lambang } \\
\text { salah membedakan tanda } \\
\text { dalam konsep serta salah } \\
\text { langkah penyelesaian } \\
\text { salah mengoperasikan }\end{array}$ \\
\hline 8. & $4:(-2)=\ldots$ & $\begin{array}{l}\text { bisa membedakan } \\
\text { tanda/lambang } \\
\text { salah membedakan tanda } \\
\text { dalam konsep serta salah } \\
\text { langkah penyelesaian } \\
\text { salah mengoperasikan }\end{array}$ & $\begin{array}{l}\text { bisa membedakan } \\
\text { tanda/lambang } \\
\text { salah membedakan tanda } \\
\text { dalam konsep sehingga } \\
\text { arah dalam penyelesaian } \\
\text { salah } \\
\text { salah mengoperasikan }\end{array}$ & $\begin{array}{l}\text { bisa membedakan } \\
\text { tanda/lambang } \\
\text { salah membedakan tanda } \\
\text { dalam konsep serta salah } \\
\text { langkah penyelesaian } \\
\text { salah mengoperasikan }\end{array}$ & $\begin{array}{l}\text { bisa membedakan } \\
\text { tanda/lambang } \\
\text { salah membedakan tanda } \\
\text { dalam konsep serta salah } \\
\text { langkah penyelesaian } \\
\text { salah mengoperasikan }\end{array}$ \\
\hline 9. & $-4: 2=\ldots$ & Soal dijawab benar & \begin{tabular}{|l} 
bisa membedakan \\
tanda/lambang \\
salah membedakan tanda \\
dalam konsep serta salah \\
langkah penyelesaian \\
salah mengoperasikan \\
\end{tabular} & $\begin{array}{l}\text { bisa membedakan } \\
\text { tanda/lambang } \\
\text { salah membedakan tanda } \\
\text { dalam konsep serta salah } \\
\text { langkah penyelesaian } \\
\text { salah mengoperasikan }\end{array}$ & $\begin{array}{l}\text { bisa membedakan } \\
\text { tanda/lambang } \\
\text { salah membedakan tanda } \\
\text { dalam konsep serta salah } \\
\text { langkah penyelesaian } \\
\text { salah mengoperasikan }\end{array}$ \\
\hline 10. & $-4:(-2)=\ldots$ & Soal dijawab benar & Soal dijawab benar & Soal dijawab benar & Soal dijawab benar \\
\hline
\end{tabular}

Faktor-Faktor yang Menyebabkan Siswa

Melakukan Kesalahan dalam Menyelesaikan

Soal-Soal Operasi Hitung Bilangan Bulat

Hasil analisis peneliti berdasarkan hasil pekerjaan siswa dan wawancara pada pemberian tes I (tes diagnostik), maka faktor-faktor yang menyebabkan terjadinya kesalahan siswa dalam menyelesaikan soal-soal operasi hitung bilangan bulat di kelas IV SD Negeri 1 Katobengke Kota Baubau adalah pada faktor ketidaktahuan siswa dalam membedakan tanda/lambang, kesalahan siswa dalam membedakan tanda dalam konsep serta salah langkah penyelesaian, dan ketidakteraturan serta kesalahan siswa dalam langkah-langkah penyelesaian soal matematika.

Berdasarkan hasil analisis tes I (tes diagnostik), faktor kesalahan siswa dalam menyelesaikan soal-soal operasi hitung campuran bilangan bulat di kelas IV SD Negeri 1 Katobengke Kota Baubau pada 10 nomor soal, maka faktor yang menyebabkan kesalahan tersebut dapat dilihat pada Tabel berikut.
Tabel 8. Faktor-Faktor yang Menyebabkan Siswa Melakukan Kesalahan dalam Menyelesaikan Soal-Soal Operasi Hitung Bilangan Bulat pada Subjek Berkategori Gaya Kognitif Field Independent (FI) dan Subjek Berkategori Gaya Kognitif Field Dependent (FD) pada Tes I

\begin{tabular}{|c|c|}
\hline $\begin{array}{l}\text { Kategori } \\
\text { kesalahan }\end{array}$ & Penyebab terjadinya kesalahan \\
\hline Kesalahan & - tidak bisa membedakan tanda/lambang \\
\hline konsep & - tidak bisa menjawab soal \\
\hline \multirow{5}{*}{$\begin{array}{l}\text { Kesalahan } \\
\text { prinsip }\end{array}$} & - salah membedakan tanda dalam \\
\hline & $\begin{array}{l}\text { konsep serta salah langkah } \\
\text { penyelesaian }\end{array}$ \\
\hline & - salah membuat penyimbolan \\
\hline & - salah menempatkan bilangannya \\
\hline & $\begin{array}{l}\text { - tanda dalam pengoperasian terkadang } \\
\text { diabaikan karena bingung }\end{array}$ \\
\hline \multirow{3}{*}{$\begin{array}{l}\text { Kesalahan } \\
\text { operasi }\end{array}$} & - salah mengoperasikan \\
\hline & - proses pengerjaan tidak teratur \\
\hline & $\begin{array}{l}\text { - pengerjaan singkat, dan hasil akhir } \\
\text { salah }\end{array}$ \\
\hline
\end{tabular}

Berdasarkan faktor penyebab terjadinya kesalahan siswa dalam menyelesaikan soal-soal operasi hitung bilangan bulat di kelas IV SD Negeri 1 Katobengke Kota Baubau pada 10 nomor soal secara keseluruhan dari 24 siswa yang menjadi subjek penelitian tes I (tes diagnostik), dimana dalam menyelesaikan soal 
La Eru Ugi, Herlawan

operasi hitung bilangan bulat pada subjek berkategori gaya kognitif Field Independent (FI) sebayak 9 siswa dan subjek berkategori gaya kognitif Field Dependent (FD) sebanyak 15 siswa dapat dilihat pada Tabel berikut.

Tabel 9. Analisis Butir Faktor Kesalahan 24 Siswa dalam Menyelesaikan 10 Nomor soal (240 Pekerjaan) Soal Tes I (Tes Diagnostik) Operasi Hitung Bilangan Bulat

\begin{tabular}{|c|c|c|c|c|c|c|c|c|c|c|c|c|c|c|c|}
\hline \multirow{2}{*}{$\begin{array}{c}\text { Gaya } \\
\text { Kognitif }\end{array}$} & \multirow{2}{*}{$\begin{array}{c}\text { Faktor } \\
\text { Kesalahan }\end{array}$} & \multicolumn{10}{|c|}{ Nomor Soal } & \multirow{2}{*}{ Total } & \multirow{2}{*}{$\begin{array}{c}\text { Kesalahan } \\
(\%)\end{array}$} & \multirow{2}{*}{$\begin{array}{c}\text { Terjawab } \\
\text { Benar } \\
(\%)\end{array}$} & \multirow{2}{*}{$\begin{array}{c}\text { Total } \\
(\%)\end{array}$} \\
\hline & & 1 & 2 & 3 & 4 & 5 & 6 & 7 & 8 & 91 & 10 & & & & \\
\hline \multirow{3}{*}{$\begin{array}{l}\text { Field } \\
\text { Independent } \\
(\mathrm{FI})\end{array}$} & Konsep & 0 & 1 & 2 & 1 & 2 & 1 & 2 & 2 & 1 & 1 & 13 & 14,44 & 85,56 & 100 \\
\hline & Prinsip & 10 & 6 & 6 & 8 & 9 & 6 & 6 & 8 & 5 & 4 & 58 & 64,44 & 35,56 & 100 \\
\hline & Operasi & 0 & 6 & 6 & 8 & 9 & 6 & 6 & 8 & 5 & 5 & 59 & 65,56 & 34,44 & 100 \\
\hline \multirow{3}{*}{$\begin{array}{l}\text { Field } \\
\text { Dependent } \\
\text { (FD) }\end{array}$} & Kons & 0 & 2 & 2 & 2 & 1 & 2 & 5 & 2 & 1 & 1 & 18 & 20,00 & 80,00 & 100 \\
\hline & Prinsip & 2 & 7 & 8 & 11 & 9 & 7 & 10 & 11 & 8 & 8 & 81 & 90,00 & 10,00 & 100 \\
\hline & Operasi & 2 & 7 & 8 & 11 & 9 & 7 & 10 & 11 & 8 & 8 & 81 & 90,00 & 10,00 & 100 \\
\hline
\end{tabular}

Berdasarkan Tabel tersebut, dari 10 nomor soal yang diberikan pada 24 subjek penelitian sehingga total soal yang dikerjakan ada 240 nomor soal. Dengan soal yang diselesaikan oleh subjek berkategori gaya kognitif Field Independent (FI) sebayak 9 siswa sehingga total soal yang dikerjakan ada 90 nomor soal dan soal yang diselesaikan oleh subjek berkategori gaya kognitif Field Dependent (FD) sebayak 15 siswa sehingga total soal yang dikerjakan ada 150 nomor soal.

Deskripsi kesalahan subjek berkategori gaya kognitif Field Independent (FI) adalah faktor kesalahan konsep siswa ada 13 pekerjaan atau $14,44 \%$ pekerjaan siswa salah pada faktor ini, sedangkan sisanya $85,56 \%$ pekerjaan siswa sudah benar. Faktor kesalahan prinsip siswa ada 58 pekerjaan atau $64,44 \%$ pekerjaan siswa salah pada faktor ini, sedangkan sisanya $35,56 \%$ pekerjaan siswa sudah benar. Faktor kesalahan operasi siswa ada 59 pekerjaan atau $65,56 \%$ pekerjaan siswa salah pada faktor ini, sedangkan sisanya $34,44 \%$ pekerjaan siswa sudah benar.

Deskripsi kesalahan subjek berkategori gaya kognitif Field Dependent (FD) adalah faktor kesalahan konsep siswa ada 18 pekerjaan atau $20,00 \%$ pekerjaan siswa salah pada faktor ini, sedangkan sisanya $80,00 \%$ pekerjaan siswa sudah benar. Faktor kesalahan prinsip siswa ada 81 pekerjaan atau $90,00 \%$ pekerjaan siswa salah pada faktor ini, sedangkan sisanya $10,00 \%$ pekerjaan siswa sudah benar. Faktor kesalahan operasi siswa ada 81 pekerjaan atau 90,00\% pekerjaan siswa salah pada faktor ini, sedangkan sisanya $10,00 \%$ pekerjaan siswa sudah benar.

Kalau dilihat kesalahan pernomor soal, kesalahan subjek berkategori gaya kognitif Field Independent (FI) pada soal nomor 1 tidak ada siswa kesalahan konsep, tidak ada siswa kesalahan prinsip, dan tidak ada siswa kesalahan operasi. Pada soal nomor 2 kesalahan konsep ada 1 siswa, kesalahan prinsip ada 6 siswa, dan kesalahan operasi ada 6 siswa. Pada soal nomor 3 kesalahan konsep ada 2 siswa, kesalahan prinsip ada 6 siswa, dan kesalahan operasi ada 6 siswa. Pada soal nomor 4 kesalahan konsep ada 1 siswa, kesalahan prinsip ada 8 siswa, dan kesalahan operasi ada 8 siswa. Pada soal nomor 5 kesalahan konsep ada 2 siswa, kesalahan prinsip ada 9 siswa, dan kesalahan operasi ada 9 siswa. Pada soal nomor 6 kesalahan konsep ada 1 siswa, kesalahan prinsip ada 6 siswa, dan kesalahan operasi ada 6 siswa. Pada soal nomor 7 kesalahan konsep ada 2 siswa, kesalahan prinsip ada 6 siswa, dan kesalahan operasi ada 6 siswa. Pada soal nomor 8 kesalahan konsep ada 2 siswa, kesalahan prinsip ada 8 siswa, dan kesalahan operasi ada 8 siswa. Pada soal nomor 9 kesalahan konsep ada 1 siswa, kesalahan prinsip ada 5 siswa, dan kesalahan operasi ada 5 siswa. Pada soal nomor 10 kesalahan konsep ada 1 siswa, kesalahan prinsip ada 4 siswa, dan kesalahan operasi ada 5 siswa.

Kesalahan subjek berkategori gaya kognitif Field Dependent (FD) pada soal nomor 1 tidak ada siswa kesalahan konsep, kesalahan prinsip ada 2 siswa, dan kesalahan operasi ada 2 siswa. Pada soal nomor 2 kesalahan konsep ada 2 siswa, kesalahan prinsip ada 7 siswa, dan kesalahan operasi ada 7 siswa. Pada soal nomor 3 kesalahan konsep ada 2 siswa, kesalahan prinsip ada 8 siswa, dan kesalahan operasi ada 6 siswa. Pada soal nomor 4 kesalahan konsep ada 2 siswa, kesalahan prinsip ada 11 siswa, dan kesalahan operasi ada 11 siswa. Pada soal nomor 5 kesalahan konsep ada 1 siswa, kesalahan prinsip 
La Eru Ugi, Herlawan

ada 9 siswa, dan kesalahan operasi ada 9 siswa. Pada soal nomor 6 kesalahan konsep ada 2 siswa, kesalahan prinsip ada 7 siswa, dan kesalahan operasi ada 7 siswa. Pada soal nomor 7 kesalahan konsep ada 5 siswa, kesalahan prinsip ada 10 siswa, dan kesalahan operasi ada 10 siswa. Pada soal nomor 8 kesalahan konsep ada 2 siswa, kesalahan prinsip ada 11 siswa, dan kesalahan operasi ada 1 siswa. Pada soal nomor 9 kesalahan konsep ada 1 siswa, kesalahan prinsip ada 8 siswa, dan kesalahan operasi ada 8 siswa. Pada soal nomor 10 kesalahan konsep ada 1 siswa, kesalahan prinsip ada 8 siswa, dan kesalahan operasi ada 8 siswa.

\section{Pemberian Alternatif Pemecahan untuk Meminimalisir Kesalahan Siswa pada Tes Diagnostik}

Adapun strategi yang dilakukan guru untuk menimalisir kesalahan yang dilakukan siswa kelas IV SD Negeri 1 Katobengke dalam menyelesaikan soal-soal opersi hitung bilangan bulat pada tes Diagnostik adalah Guru kelas IV menimalisirnya dengan menggunakan media berupa alat peraga, alat peraga disini biasanya dengan menggunakan garis bilangan. Untuk mengatasi kesalahan siswa dalam menyelesaikan soal-soal operasi hitung bilangan bulat, guru perlu mengenal berbagai kesalahan yang dilakukan oleh anak dalam menyelesaikan soalsoal matematika. Beberapa kekeliruan umum tersebut menurut Lerner dalam Abdurrahman (2012) adalah kekurangangan pemahaman 1) simbol, 2) nilai tempat, 3) perhitungan, 4) penggunaan proses yang keliru, dan 5) tulisan yang tidak terbaca.

Adapun tahap-tahap pengembangan strategi guru tersebut dengan Prinsip kerja yang harus diperhatikan dalam melakukan operasi penjumlahan maupun pengurangan dengan menggunakan alat ini adalah: (1) Posisi awal benda yang menjadi model harus berada pada skala nol. (2) Jika bilangan pertama positif, maka bagian muka model menghadap ke bilangan positif dan kemudian melangkahkan model tersebut ke skala yang sesuai dengan besarnya bilangan pertama tersebut. Proses yang sama juga dilakukan apabila bilangan pertamanya bertanda negatif. (3) Jika model dilangkahkan maju, dalam prinsip operasi hitung istilah maju diartikan sebagai tambah (+), sedangkan jika model dilangkahkan mundur, istilah mundur diartikan sebagai kurang (-). (4) Gerakan maju atau mundurnya model tergantung dari bilangan penambah dan pengurangnya. Untuk gerakan maju, jika bilangan penambahnya merupakan bilangan positif maka model bergerak maju ke arah bilangan positif, dan sebaliknya jika bilangan penambahnya merupakan bilangan negatif, maka model bergerak maju ke arah bilangan negatif. Untuk gerakan mundur, apabila bilangan pengurangnya merupakan bilangan positif maka model bergerak mundur dengan sisi model menghadap ke bilangan positif, dan sebaliknya apabila bilangan pengurangnya merupakan bilangan negatif, maka model bergerak mundur dengan sisi muka menghadap ke bilangan negatif.

Adapun cara lain yang digunakan guru agar siswa lebih mengerti proses pengertjaan soal operasi dengan bilangan bulat dengan sistem lompatan atau langkah dimana tiap langkah berjumlah satu satuan, kalau tanda (+) semakin besar atau bergerak majudan tanda (-) semakin kecil dan bergerak mundur, adapun tanda (-) diibaratkan utang. Berdasarkan soal dari jawaban siswa yang masih melakukan kesalahan pada soal yang sama pada tes diagnostik dan soal pada tes II dengan menggunakan garis bilangan adalah: 3 $+(-5)=\ldots$.

Adapun teknik atau cara mengerjakan dengan menggunakan garis bilangan: Dari skala 0, langkahkanlah anak panah ke arah bilangan positif dan berhenti pada skala 3. Hal ini untuk menunjukan bilangan pertamanya (positif 3 )

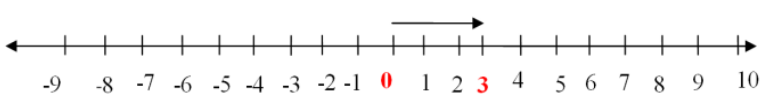

Kemudian anak panah arahnya sesuai dengan jenis bilangan keduanya, maka langkahkanlah mundur anak panah tersebut sebanyak 5 langkah dari posisi skala 3

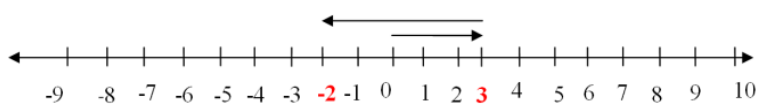

Posisi terakhir ujung panah pada langkah kedua berada di atas skala -2 , dan ini menunjukan hasil dari $3+(-5)=-2$. Jadi $3+(-5)=-2$.

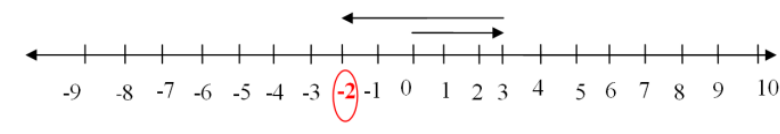

\section{Pemberian Tes II (Tes Diagnostik Setelah Tindakan)}

Setelah pemberian strategi alternatif mengatasi kesalahan, siswa diberikan tes kembali guna melihat bahwa alternatif yang digunakan dalam mengatasi kesalahan tersebut dapat mengurangi tingkat kesalahan yang dilakukan 
La Eru Ugi, Herlawan

oleh siswa kelas IV SD Negeri 1 Katobenke. Berikut ini diuraikan hasil tes setelah pemberian strategi alternatif mengatasi kesalahan siswa serta deskripsi kesalahan siswa pada tes tersebut. Pemberian tes II (tes diagnostik setelah tindakan) dilaksanakan pada hari senin, tanggal 23 April 2018 pada siswa kelas IV SD Negeri 1 Katobengke sebanyak 24 siswa. Sama halnya seperti tes I (tes diagnostik), pemberian tes II (tes diagnostik setelah tindakan) ini juga diawasi oleh peneliti dan guru kelas IV untuk menjaga keobjektifan jawaban siswa. Hasil tes II ini selanjutnya diperiksa dan dianalisis oleh peneliti.

Deskripsi Kesalahan Siswa dalam Menyelesaikan Soal-Soal Operasi Hitung Bilangan Bulat pada Tes II (Tes Diagnostik Setelah Tindakan) dan Penyebabnya

Siswa yang terpilih pada wawancara pada tes I diwanwancarai kembali untuk memperoleh lebih banyak informasi mengenai berkurangnya kesalahan-kesalahan yang dilakukan pada soalsoal operasi hitung bilangan bulat. Deskripsi kesalahan siswa dalam menyelesaikan soal-soal operasi hitung bilangan bulat pada kategori siswa FI (Field independent) dan pada kategori siswa FD (Field Dependent).

Hasil Tes II (Tes Diagnostik Setelah Tindakan) Subjek Kategori dengan Gaya Kognitif FieldIndependent (FI)

Subjek FAL $\left(\boldsymbol{F I}_{1}\right)$

Penggalan jawaban tes diagnostik pada soal nomor 3

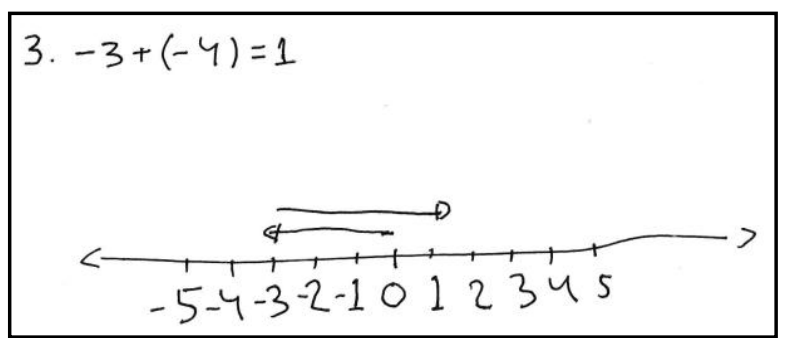

Gambar 5. Penggalan Jawaban Tes II (Tes Diagnostik Setelah Tindakan) pada Soal Nomor 3 Inisial FAL
Penggalan hasil tes di atas menggambarkan kalau subjek FAL masih belum memahami prinsip penjumlahan negatif. Tetapi berdasarkan jawaban di atas bisa dikatakan bahwa siswa FAL tersebut mengetahui konsep dalam soal. Karena kesalahan prinsip sehingga operasi yang dilakukan juga jadi salah dimana jawaban akhir siswa tersebut adalah 1 .

Penggalan jawaban tes diagnostik pada soal nomor 10

$$
\begin{aligned}
& \text { 10. }-9:(-3)=-3 \\
& \text { karena ada negatif, raka hasilnya negatif } \\
&-9:(-3)=-3
\end{aligned}
$$

Gambar 6. Penggalan Jawaban Tes II (Tes Diagnostik Setelah Tindakan) pada Soal Nomor 10 Inisial FAL

Penggalan hasil tes di atas menggambarkan kalau subjek FAL masih bingung dengan bilangan negatif. Ini membuktikan dia hanya memperhatikan negatif dalam penyelesaian walaupun hasih baginya bisa dikatakan dia bisa selesaikan. Penggalan jawaban di atas konsep sudah benar, namun prinsip dan operasinya salah. Dalam penyelesaian di atas bisa dilihat siswa lebih dahulu menyelesaiakn hitungan 9:3=3 kemudian negetif tinggal diperkirakan oleh siswa ini. Sehingga hasil akhir yang diperolehnya adalah -3 . 
La Eru Ugi, Herlawan

Tabel 10. Rekapitulasi Kesalahan dan Penyebab Kesalahan dalam Menyelesaikan Soal pada Subjek Berkategori Gaya Kognitif Field Independent (FI) dan Subjek Berkategori Gaya Kognitif Field Dependent (FD) pada Tes II

\begin{tabular}{|c|c|c|c|c|c|}
\hline \multirow{2}{*}{ No. } & \multirow{2}{*}{ Soal } & \multicolumn{2}{|c|}{ Subkek FI } & \multicolumn{2}{|c|}{ Subjek FD } \\
\hline & & FAL & ARF & MNR & WEG \\
\hline 1. & $3+(-5)=\ldots$ & Soal dijawab benar & Soal dijawab benar & Soal dijawab benar & Soal dijawab benar \\
\hline 2. & $-2+4=\ldots$ & Soal dijawab benar & Soal dijawab benar & Soal dijawab benar & Soal dijawab benar \\
\hline 3. & $-3+(-4)=\ldots$ & $\begin{array}{l}\text { bisa membedakan } \\
\text { tanda/lambang } \\
\text { salah membedakan } \\
\text { konsep serta salah } \\
\text { langkah penyelesaian } \\
\text { salah mengoperasikan }\end{array}$ & Soal dijawab benar & Soal dijawab benar & Soal dijawab benar \\
\hline 4. & $2-(-4)=\ldots$ & Soal dijawab benar & Soal dijawab benar & Soal dijawab benar & $\begin{array}{l}\text { bisa membedakan } \\
\text { tanda/lambang } \\
\text { salah membedakan } \\
\text { konsep serta salah } \\
\text { langkah penyelesaian } \\
\text { salah mengoperasikan }\end{array}$ \\
\hline 5. & $-4-(-3)=\ldots$ & Soal dijawab benar & Soal dijawab benar & $\begin{array}{l}\text { bisa membedakan } \\
\text { tanda/lambang } \\
\text { salah membedakan } \\
\text { konsep serta salah } \\
\text { langkah penyelesaian } \\
\text { salah mengoperasikan }\end{array}$ & Soal dijawab benar \\
\hline 6. & $-2 \times 7=\ldots$ & Soal dijawab benar & Soal dijawab benar & Soal dijawab benar & Soal dijawab benar \\
\hline 7. & $-5 \times(-3)=\ldots$ & Soal dijawab benar & Soal dijawab benar & Soal dijawab benar & $\begin{array}{l}\text { bisa membedakan } \\
\text { tanda/lambang } \\
\text { salah membedakan } \\
\text { konsep serta salah } \\
\text { langkah penyelesaian } \\
\text { salah mengoperasikan } \\
\end{array}$ \\
\hline 8. & $9:(-3)=\ldots$. & Soal dijawab benar & $\begin{array}{l}\text { bisa membedakan } \\
\text { tanda/lambang } \\
\text { salah membedakan } \\
\text { konsep serta salah } \\
\text { langkah penyelesaian } \\
\text { salah mengoperasikan } \\
\end{array}$ & Soal dijawab benar & Soal dijawab benar \\
\hline 9. & $-8: 4=\ldots$ & Soal dijawab benar & Soal dijawab benar & Soal dijawab benar & Soal dijawab benar \\
\hline 10. & $-9:(-3)=\ldots$ & $\begin{array}{l}\text { bisa membedakan } \\
\text { tanda/lambang } \\
\text { salah membedakan } \\
\text { konsep serta salah } \\
\text { langkah penyelesaian } \\
\text { salah mengoperasikan }\end{array}$ & Soal dijawab benar & Soal dijawab benar & Soal dijawab benar \\
\hline
\end{tabular}

Faktor-Faktor yang Menyebabkan Siswa Melakukan Kesalahan dalam Menyelesaikan Soal-Soal Operasi Hitung Bilangan Bulat

Hasil analisis peneliti berdasarkan hasil pekerjaan siswa pada pemberian tes II, maka faktor-faktor yang menyebabkan terjadinya kesalahan siswa dalam menyelesaikan soal-soal operasi hitung bilangan bulat di kelas IV SD Negeri 1 Katobengke Kota Baubau yang sama halnya seperti tes I (tes diagnostik) adalah pada faktor ketidaktahuan siswa dalam membedakan tanda/lambang, kesalahan siswa dalam membedakan tanda dalam konsep serta salah langkah penyelesaian, dan ketidakteraturan serta kesalahan siswa dalam langkah-langkah penyelesaian soal matematika.

Berdasarkan hasil analisis tes II ini, faktor kesalahan siswa dalam menyelesaikan soal-soal operasi hitung campuran bilangan bulat di kelas IV SD Negeri 1 Katobengke Kota Baubau pada 10 nomor soal secara keseluruhan dari 24 siswa yang menjadi subjek penelitian dapat dilihat pada Tabel berikut. 
Tabel 11. Faktor-Faktor yang Menyebabkan Siswa Melakukan Kesalahan dalam Menyelesaikan Soal-Soal Operasi Hitung Bilangan Bulat pada Subjek Berkategori Gaya Kognitif Field Independent (FI) dan Subjek Berkategori Gaya Kognitif Field Dependent (FD) pada Tes II

\begin{tabular}{ll}
\multicolumn{1}{c}{$\begin{array}{c}\text { Kategori } \\
\text { kesalahan }\end{array}$} & \multicolumn{1}{c}{ Penyebab terjadinya kesalahan } \\
\hline $\begin{array}{l}\text { Kesalahan } \\
\text { konsep }\end{array}$ & - tidak bisa membedakan tanda/lambang \\
Kesalahan & - salah membedakan tanda dalam \\
prinsip & konsep serta salah langkah \\
& penyelesaian \\
& - salah membuat penyimbolan \\
& - salah menempatkan bilangannya \\
& - tanda dalam pengoperasian terkadang \\
& diabaikan \\
Kesalahan & - salah mengoperasikan \\
operasi & - proses pengerjaan tidak teratur \\
& - pengerjaan singkat, dan hasil akhir \\
& salah \\
\hline
\end{tabular}

Berdasarkan faktor penyebab terjadinya kesalahan siswa dalam menyelesaikan soal-soal operasi hitung bilangan bulat di kelas IV SD Negeri 1 Katobengke Kota Baubau pada 10 nomor soal secara keseluruhan dari 24 siswa yang menjadi subjek penelitian tes II (tes diagnostik setelah tindakan), dimana dalam menyelesaikan soal operasi hitung bilangan bulat pada subjek berkategori gaya kognitif Field Independent (FI) sebayak 9 siswa dan subjek berkategori gaya kognitif Field Dependent (FD) sebanyak 15 siswa dapat dilihat pada Tabel berikut.

Tabel 12. Analisis Butir Faktor Kesalahan 24 Siswa dalam Menyelesaikan 10 Nomor soal (240 Pekerjaan) Soal Tes II (Tes Diagnostik Setelah Tindakan) Operasi Hitung Bilangan Bulat

\begin{tabular}{|c|c|c|c|c|c|c|c|c|c|c|c|c|c|c|}
\hline \multirow{2}{*}{$\begin{array}{c}\text { Gaya } \\
\text { Kognitif }\end{array}$} & \multirow{2}{*}{$\begin{array}{c}\text { Faktor } \\
\text { Kesalahan }\end{array}$} & \multicolumn{9}{|c|}{ Nomor Soal } & \multirow{2}{*}{ Total } & \multirow{2}{*}{$\begin{array}{c}\text { Kesalahan } \\
(\%)\end{array}$} & \multirow{2}{*}{$\begin{array}{c}\text { Terjawab } \\
\text { Benar } \\
(\%)\end{array}$} & \multirow{2}{*}{$\begin{array}{c}\text { Total } \\
(\%)\end{array}$} \\
\hline & & 1 & & 3 & 45 & 6 & 7 & 8 & & 10 & & & & \\
\hline Field & Konsep & 0 & 0 & 1 & 00 & 0 & 0 & 0 & 0 & 0 & 1 & 1,11 & 98,89 & 100 \\
\hline Independent & Prinsip & 0 & 3 & 3 & 43 & 2 & 2 & 2 & 2 & 1 & 22 & 24,44 & 75,56 & 100 \\
\hline$(\mathrm{FI})^{\mathrm{I}}$ & Operasi & 0 & 3 & 3 & 43 & 2 & 2 & 2 & 2 & 2 & 23 & 25,56 & 74,44 & 100 \\
\hline Field & Konsep & 0 & 0 & 0 & $0 \quad 0$ & 0 & 0 & 1 & 1 & 1 & 3 & 3,33 & 96,67 & 100 \\
\hline Dependent & Prinsip & 1 & 3 & 4 & 31 & 2 & 5 & 4 & 3 & 6 & 32 & 35,56 & 64,44 & 100 \\
\hline (FD) & Operasi & 1 & 3 & 4 & 32 & 2 & 6 & 4 & 3 & 6 & 34 & 37,78 & 62,22 & 100 \\
\hline
\end{tabular}

Berdasarkan Tabel 5.35 tersebut, dari 10 nomor soal yang diberikan pada 24 subjek penelitian sehingga total soal yang dikerjakan ada 240 nomor soal. Dengan soal yang diselesaikan oleh subjek berkategori gaya kognitif Field Independent (FI) sebayak 9 siswa sehingga total soal yang dikerjakan ada 90 nomor soal dan soal yang diselesaikan oleh subjek berkategori gaya kognitif Field Dependent (FD) sebayak 15 siswa sehingga total soal yang dikerjakan ada 150 nomor soal.

Deskripsi kesalahan subjek berkategori gaya kognitif Field Independent (FI) adalah faktor kesalahan konsep siswa ada 1 pekerjaan atau $1,11 \%$ pekerjaan siswa salah pada faktor ini, sedangkan sisanya $98,89 \%$ pekerjaan siswa sudah benar. Faktor kesalahan prinsip siswa ada 22 pekerjaan atau $24,44 \%$ pekerjaan siswa salah pada faktor ini, sedangkan sisanya $75,56 \%$ pekerjaan siswa sudah benar. Faktor kesalahan operasi siswa ada 23 pekerjaan atau 25,56\% pekerjaan siswa salah pada faktor ini, sedangkan sisanya $74,44 \%$ pekerjaan siswa sudah benar.

Deskripsi kesalahan subjek berkategori gaya kognitif Field Dependent (FD) adalah faktor kesalahan konsep siswa ada 3 pekerjaan atau $3,33 \%$ pekerjaan siswa salah pada faktor ini, sedangkan sisanya $96,67 \%$ pekerjaan siswa sudah benar. Faktor kesalahan prinsip siswa ada 32 pekerjaan atau $35,56 \%$ pekerjaan siswa salah pada faktor ini, sedangkan sisanya $64,44 \%$ pekerjaan siswa sudah benar. Faktor kesalahan operasi siswa ada 34 pekerjaan atau 37,78\% pekerjaan siswa salah pada faktor ini, sedangkan sisanya $62,22 \%$ pekerjaan siswa sudah benar. 
La Eru Ugi, Herlawan

Kalau dilihat kesalahan pernomor soal, kesalahan subjek berkategori gaya kognitif Field Independent (FI) pada soal nomor 1 tidak ada siswa kesalahan konsep, tidak ada siswa kesalahan prinsip, dan tidak ada siswa kesalahan operasi. Pada soal nomor 2 tidak ada siswa kesalahan konsep, kesalahan prinsip ada 3 siswa, dan kesalahan operasi ada 3 siswa. Pada soal nomor 3 kesalahan konsep ada 1 siswa, kesalahan prinsip ada 3 siswa, dan kesalahan operasi ada 3 siswa. Pada soal nomor 4 tidak ada siswa kesalahan konsep, kesalahan prinsip ada 4 siswa, dan kesalahan operasi ada 4 siswa. Pada soal nomor 5 tidak ada siswa kesalahan konsep, kesalahan prinsip ada 3 siswa, dan kesalahan operasi ada 3 siswa. Pada soal nomor 6 tidak ada siswa kesalahan konsep, kesalahan prinsip ada 2 siswa, dan kesalahan operasi ada 2 siswa. Pada soal nomor 7 tidak ada siswa kesalahan konsep, kesalahan prinsip ada 2 siswa, dan kesalahan operasi ada 2 siswa. Pada soal nomor 8 tidak ada siswa kesalahan konsep, kesalahan prinsip ada 2 siswa, dan kesalahan operasi ada 2 siswa. Pada soal nomor 9 tidak ada siswa kesalahan konsep, kesalahan prinsip ada 2 siswa, dan kesalahan operasi ada 2 siswa. Pada soal nomor 10 tidak ada siswa kesalahan konsep, kesalahan prinsip ada 1 siswa, dan kesalahan operasi ada 2 siswa.
Kesalahan subjek berkategori gaya kognitif Field Dependent (FD) pada soal nomor 1 tidak ada siswa kesalahan konsep, kesalahan prinsip ada 1 siswa, dan kesalahan operasi ada 1 siswa. Pada soal nomor 2 tidak ada siswa kesalahan konsep, kesalahan prinsip ada 3 siswa, dan kesalahan operasi ada 3 siswa. Pada soal nomor 3 tidak ada siswa kesalahan konsep, kesalahan prinsip ada 4 siswa, dan kesalahan operasi ada 4 siswa. Pada soal nomor 4 tidak ada siswa kesalahan konsep, kesalahan prinsip ada 3 siswa, dan kesalahan operasi ada 3 siswa. Pada soal nomor 5 tidak ada siswa kesalahan konsep, kesalahan prinsip ada 1 siswa, dan kesalahan operasi ada 2 siswa. Pada soal nomor 6 tidak ada siswa kesalahan konsep, kesalahan prinsip ada 2 siswa, dan kesalahan operasi ada 2 siswa. Pada soal nomor 7 tidak ada siswa kesalahan konsep, kesalahan prinsip ada 5 siswa, dan kesalahan operasi ada 6 siswa. Pada soal nomor 8 kesalahan konsep ada 1 siswa, kesalahan prinsip ada 4 siswa, dan kesalahan operasi ada 4 siswa. Pada soal nomor 9 kesalahan konsep ada 1 siswa, kesalahan prinsip ada 3 siswa, dan kesalahan operasi ada 3 siswa. Pada soal nomor 10 kesalahan konsep ada 1 siswa, kesalahan prinsip ada 6 siswa, dan kesalahan operasi ada 6 siswa.

Tabel 13. Perubahan Persentase Kesalahan pada Tes I (Tes Diagnostik) dan Tes II (Tes Diagnostik Setelah Tindakan) Operasi Hitung Bilangan Bulat

\begin{tabular}{llcc}
\hline \multicolumn{1}{c}{ Gaya Kognitif } & Faktor Kesalahan & $\begin{array}{c}\text { Kesalahan Tes I } \\
\text { (Tes Diagnostik) } \\
(\%)\end{array}$ & $\begin{array}{c}\text { Kesalahan Tes II } \\
\text { (Tes Diagnostik } \\
\text { Setelah Tindakan) } \\
(\%)\end{array}$ \\
\hline Field Independent & Konsep & 14,44 & 1,11 \\
(FI) & Prinsip & 64,44 & 24,44 \\
& Operasi & 65,56 & 25,56 \\
Field Dependent & Konsep & 20,00 & 3,33 \\
(FD) & Prinsip & 90,00 & 35,56 \\
\hline
\end{tabular}

Berdasarkan Tabel di atas, tampak bahwa kesalahan siswa dalam mengerjakan soal operasi hitung bilangan bulat dari Tes I (Tes Diagnostik) dan Tes II (Tes Diagnostik Setelah Tindakan) sedikit berkurang. Kesalahan subjek berkategori gaya kognitif Field Independent (FI) adalah kesalahan konsep dari $14,44 \%$ berkurang menjadi $1,11 \%$, kesalahan prinsip dari $64,44 \%$ berkurang menjadi $24,44 \%$, dan kesalahan operasi dari $65,56 \%$ berkurang menjadi $25,56 \%$. Kesalahan subjek berkategori gaya kognitif Field Dependent (FD) adalah kesalahan konsep dari 20,00\% berkurang menjadi 3,33\%, kesalahan prinsip dari $90,00 \%$ berkurang menjadi $35,56 \%$, dan kesalahan operasi dari $90,00 \%$ berkurang menjadi 37,78\%. Ini dimaksudkan bahwa perlakuan yang tepat dapat mengurangi kesalahan-kesalahan siswa dalam menyelesaikan soal operasi hitung bilangan bulat, baik itu subjek berkategori gaya kognitif Field Independent (FI) maupun subjek berkategori gaya kognitif Field Dependent (FD). 
La Eru Ugi, Herlawan

\section{KESIMPULAN DAN SARAN}

\section{Kesimpulan}

Berdasarkan hasil dan pembahasan serta temuan penelitian yang telah dikemukan, maka beberapa kesimpulan dapat dikemukakan, yaitu: 1) Kesalahan-kesalahan yang dilakukan oleh siswa kelas IV SD Negeri 1 Katobengke Kota Baubau dalam menyelesaikan soal-soal operasi hitung bilangan bulat ditinjau dari gaya kongnitifnya: a) pada subjek berkategori gaya kognitif Field Independent (FI) adalah siswa tidak memahami soal, salah membedakan konsep serta salah langkah penyelesaian, dan salah dalam mengoperasikan. b) pada subjek berkategori gaya kognitif Field Dependent (FD) adalah siswa tidak bisa membedakan tanda/lambang, salah membedakan tanda dalam konsep serta salah langkah penyelesaian, dan salah dalam mengoperasikan. 2) Faktor-faktor yang menyebabkan siswa melakukan kesalahan dalam menyelesaikan soal- soal operasi hitung bilangan bulat di Kelas IV SD Negeri 1 Katobengke Kota Baubau ditinjau dari gaya kognitifnya yaitu pada subjek berkategori gaya kognitif Field Independent (FI) dan pada subjek berkategori gaya kognitif Field Dependent (FD) adalah pada kesalahan konsep: tidak bisa membedakan tanda/lambang, tidak bisa menjawab soal; pada kesalahan prinsip: salah membedakan tanda dalam konsep serta salah langkah penyelesaian, salah membuat penyimbolan, salah menempatkan bilangannya, tanda dalam pengoperasian terkadang diabaikan karena bingung; dan pada kesalahan operasi: salah mengoperasikan, proses pengerjaan tidak teratur, pengerjaan singkat, dan hasil akhir salah. 3) Alternatif pemecahan yang dinilai baik untuk memperbaiki kesalahan dalam menyelesaikan soal-soal operasi hitung bilangan bulat di Kelas IV SD Negeri 1 Katobengke Kota Baubau adalah dengan menggunakan media berupa alat peraga, alat peraga disini biasanya dengan menggunakan garis bilangan.

\section{Saran}

Berdasarkan deskripsi pembahasan hasil penelitian dan kesimpulan di atas, maka dapat disarankan kepada: 1) Bagi guru, Guru hendaknya membiasakan siswa untuk mengerjakan soal secara sistematis yang mulai dari apa yang ditanyakan, diketahui hingga pada kesimpulan akhir. Guru harus menanamkan konsep, prinsip, dan operasi dalam setiap menyelesaikan soal matematikanya. Guru matematika juga perlu tahu gaya kognitif siswanya dalam memecahkan masalah matematika terutama pemahaman konsep, prinsip, dan operasi hitung bilangan bulat agar dapat menunjang kegiatan pembelajaran di kelas. Guru hendaknya membiasakan siswa untuk menggunakan media secara konsisten dalam mengerjakan soal, tidak hanya diajar dengan menggunakan cara dan teknik biasa agar siswa lebih termotivasi dalam mengerjakan masalah dalam matematika. Untuk mengatasi kesalahan dalam menyelesaikan soal-soal pada operasi hitung bilangan bulat,guru hendaknya membiasakan melakukan pengulangan materi yang dianggap sulit,memberikan tugas dengan baik secara individu maupun kelompok dan memperhatikan pula gaya kognitif tiap anak didik. 2) Peneliti dan pemerhati pendidikan dan pengajaran untuk menindak-lanjuti temuantemuan dalam penelitian ini, khususnya hal-hal yang terkait dengan kemampuan siswa dalam menyelesaikan masalah matematika berdasarkan kesalahan dan gaya kognitif siswa.

\section{DAFTAR PUSTAKA}

[1] Abdurrahman, M. 2012. Anak Berkesulitan Belajar (Teori, Diagnosis, dan Remediasinya). Jakarta: Reneka Cipta.

[2] Amin, R, M. 2010. Deskripsi Kemampuan Siswa SMP Negeri 4 Sungguminasa Dalam Memecahkan Masalah Matematika OpenEnded (Ditinjau Dari Perbedaan Tingkat Kemampuan Prasyarat dan Gaya Kognitif). Tesis: Program Pascasarjana Universitas Negeri Makassar.

[3] Azwar, S. 2015. Sikap Manusia: Teori dan Pengukurannya Edisi ke-2. Yogyakarta. Pustaka Pelajar.

[4] Bramasti, R. 2012. Kamus Matematika. Surakarta: Aksara Sinergi Media.

[5] Hamzah, U, B. 2012. Orientasi Baru dalam Psikologi Pembelajaran. Jakarta: PT. Bumi Aksara.

[6] Jamaris, M. 2013. Kesulitan Belajar: Persepsi, Asesmen, dan Penanggulangannya Bagi Anak Usia Dini dan Usia Sekolah. Jakarta. Ghalia Indonesia.

[7] Muhsetyo. G.dkk.2010. Pembelajaran Matematika SD. Jakarta: Universitas Terbuka. Mustaqim, B. \& Astuty, A. 2008. Ayo Belajar Matematika (untuk SD dan MI 
Kelas IV). Pusat Pembukaan Departemen Pendidikan Nasional.

[8] Nasution, M. A, 2008. Berbagai pendekatan dalam proses belajar dan mengajar. Jakarta. Bumi Aksara.

[9] Sagala, S. 2010. Konsep dan Makna Pembelajaran. Bandung: Alfabeta.

[10] Shadiq, F., \& Ini, P. P. S. 2006. Implikasi konstruktivisme dalam pembelajaran matematika Sekolah dasar. Artikel. Retrieved from https://xa.yimg.com/kq/groups/86526203/10 96620064/name/KONTRUKTIVISME+MA T+SD.pdf. Diakses 12 Desember 2016.

[11] Suwarto. 2013. Pengembangan Tes Diagnotik Dalam Pembelajaran (Paduan Praktis bagi Pendidik dan Calon Pendidik). Yogyakarta:Pustaka Belajar.

[12] Tiro, M. A. dkk,. 2018. Pengenalan T eori Bilangan. Makassar: Andira Publisher.

[13] Ulifa, S. N. 2014. Hasil Analisis Kesalahan Siswa Dalam Menelesaikan soal Matematika Pada Mataeri Relasi. Jurnal Pendidikan Matematika STKIP PGRI Sidoarjo, ISSN: 2337-8166, Vol. 2 No. 1, Maret 2014. Diakses 13 Desember 2016

[14] Wiyartimi, dkk. 2012. Diagnosis Kesulitan Belajar Matematika Siswa pada Materi 


\section{Jurnal Akademik Pendidikan Matematika FKIP Unidayan Baubau}

Volume IV, Nomor 2, November 2018

Analisis Kemampuan Pemahaman Pengetahuan Mahasiswa pada Mata Kuliah Statistik Matematika

Oleh: Azis, Maya Nurlita

Penggunaan Lampu LED untuk Meningkatkan Pemahaman Konsep PLSV pada Siswa Kelas VII-B di SMP Negeri 18 Baubau

Oleh: Amhari

Peningkatan Penguasaan Operasi Bilangan Bulat dengan Teknik Permainan Kocok-Kocok untuk Siswa Kelas VII A SMP Negeri 3 Baubau

Oleh: Fariati

Efektivitas Model Pembelajaran Tematik Terhadap Prestasi Siswa Kelas III SD Negeri 1 Kambowa

Oleh: Artati Iriana

Meningkatkan Keterampilan Berhitung Peserta Didik pada Operasi Hitung Bilangan Bulat dengan Penggunaan Media Kelereng Warna Untuk Kelas II Sekolah Dasar

Oleh: Ernawati Jais, Fadly Satryo Guntara All Farisman

IDEA (Identification Ethnomathematic of Architecture) Benteng Keraton Buton: Identifikasi Etnomatematika (Bilangan dan Geometri) pada Arsitektur Benteng Keraton Buton

Oleh: Dian Lestari, Rustam

Efektivitas Model Pembelajaran CTL (Contextual Teaching and Learning) Terhadap Penalaran Matematika Siswa Kelas VIII SMP Negeri 3 Pasarwajo

Oleh: Rahmatia, Norma Usu

Analisis Kesalahan Siswa dalam Menyelesaikan Soal-Soal Operasi Hitung Bilangan Bulat dan Alternatif Pemecahannya Ditinjau Dari Gaya Kognitif Siswa Kelas IV SD Negeri 1 Katobengke Kota Baubau

Oleh: La Eru Ugi, Herlawan

Pengaruh Strategi Berhitung (Different Strategies) Terhadap Hasil Belajar Matematika Siswa SD Negeri 4 Wameo

Oleh: Anwar, Muhammad Rifai

Integrasi Etnomatematik Budaya Pohamba-Hamba (Gotong Royong) pada Pembuatan Talang Poromu (Talang Persatuan) pada Masyarakat Adat Buton Kota Baubau

Oleh: Sardin, Amaluddin

Eksplorasi Etnomatematika dalam Adat Perhitungan Mahar Pernikahan Masyarakat Buton Oleh: Wa Ode Irma Rahmawati, La Eru Ugi, Herno, Artati Iriana

Eksplorasi Etnomatematika Rumah Adat Masyarakat Buton

Oleh: Herno

Analisis Kesalahan Siswa pada Pengoperasian Perkalian Bersusun pada Kelas IV SD Negeri 2 Baubau Ditinjau Dari Gaya Kognitif Siswa

Oleh: Rismayani Armin, Artati Iriana

Fakultas Keguruan dan Ilmu Pendidikan

ISSN 2442-9864

Universitas Dayanu Ikhsanuddin

Baubau 2018

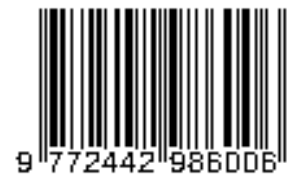

